\title{
Leadership, Membership, and Voice: Civic Associations That Work ${ }^{1}$
}

\author{
Kenneth T. Andrews \\ University of North Carolina, \\ Chapel Hill
}

Matthew Baggetta

Harvard University

Chaeyoon Lim

University of Wisconsin-Madison

\author{
Marshall Ganz \\ Harvard University
}

Hahrie Han

Wellesley College

\begin{abstract}
Why are some civic associations more effective than others? The authors introduce a multidimensional framework for analyzing the effectiveness of civic associations in terms of public recognition, member engagement, and leader development. Using original surveys of local Sierra Club organizations and leaders, the authors assess prevailing explanations in organization and movement studies alongside a model highlighting leadership and internal organizational practices. Although available resources and favorable contexts matter, the core findings show that associations with more committed activists, that build organizational capacity, that carry out strong programmatic activity, and whose leaders work independently, generate greater effectiveness across outcomes.
\end{abstract}

For much of our history, civic associations served as the "great free schools of democracy" (Tocqueville [1835-40] 1969). By associating with one another, individuals in associations learned both to discern their common interests and collectively mobilize individual resources to act on those

\footnotetext{
${ }^{1}$ As principal investigators for the National Purpose Local Action project and senior authors for this article, Andrews and Ganz contributed equally, and their names are listed alphabetically. In carrying out this project, we benefited from the contributions of Steve Baru, Greg Cassini, Jessica Mele, Lisa Renstrom, Julia Reitan, and Sarah Staley. Our argument and analyses were strengthened through feedback on presentations at MIT, Tufts, Harvard, and at the American Sociological Association meetings. We are grateful to Richard Hackman, Mark Moore, Robert Putnam, Sarah Soule, and
}

(C) 2010 by The University of Chicago. All rights reserved.

0002-9602/2010/11504-0006\$10.00

AJS Volume 115 Number 4 (January 2010): 1191-1242 
American Journal of Sociology

interests. Making their voices heard through collective action thus required mastering the leadership arts, especially those required for selfgovernment. As voluntary associations, the capacity of civic associations for collective action depended on their members' contributions of money, time, effort, and skill to common purpose. The efficacy of their leadership thus lay in their ability to mobilize and direct the commitment, accountability, and cooperation of voluntary participants. Their success in achieving their goals rested on the extent to which they could make their voices heard in the public arena.

Because of the way they are organized, the purposes for which they are organized, and the ways they exercise influence, civic associations play a major role not only in creating civic infrastructure but in incubating social movements and acting as the dominant organizational form into which movements evolve. As Skocpol, Ganz, and Munson (2000) show, of the 46 civic associations that encompassed $1 \%$ or more of the U.S. population between 1776 and 1955, 17 of them incubated or institutionalized social movements. These included the Sons of Temperance, the American Abolition Society, the Farmers Alliance, the Women's Christian Temperance Union, the Women's Suffrage Association, the Knights of Labor, and the Ku Klux Klan. This contribution to the emergence and institutionalization of social movements derives from civic associations' need to facilitate collective action, generate and sustain member commitment, and provide opportunities for new leadership to emerge.

Civic associations operate in profoundly different ways than for-profit or nonprofit bureaucratic organizations in which decision making is highly centralized, work is done by hired employees, and goals concern the delivery of goods or services to external customers or clients who enjoy no authority to choose leaders or decide policy (Wilson 1973; Knoke and Prensky 1984; Smith 2000). In contrast, civic associations depend upon voluntary efforts of their members, decentralize decision making across local units, govern themselves through elected volunteer leaders, and enable their members' collective voices to be heard. They thus interact with constituents, not customers or clients (Gecan 2004). Their authority rests on moral suasion rather than economic or political coercion. Their outputs require the voluntary participation of members and supporters (Knoke and Prensky 1984; Smith 2000). Leadership practices required to generate

the $A J S$ reviewers for constructive criticism. The research was supported by funding from the Milton Fund, the Center for Public Leadership, the Hauser Center at Harvard's Kennedy School, and the Sierra Club Foundation. Direct correspondence to Kenneth T. Andrews, Department of Sociology CB\#32 10, University of North Carolina, Chapel Hill, North Carolina 27599, or Marshall Ganz, Hauser Center, Kennedy School of Government, Harvard University, Cambridge, Massachusetts 02138. Email: kta@ unc.edu or Marshall_Ganz@harvard.edu 
compliance in work organizations differ substantially from those required to generate commitment in voluntary ones (Walton 1985). These differences are the principal reason many argue that a trend replacing civic associations with professional advocacy or service providers is eroding valuable civic infrastructure (Weir and Ganz 1997; Putnam 2000; Skocpol 2003; Walker 2009).

But not all civic associations are in decline. Some continue to develop leaders, engage members, and make their voices heard in the public arena. They offer scholars an opportunity to learn how they work, why they work, and how they could work better. The local affiliates of federated national civic associations comprise an estimated $25 \%$ of all local social movement organizations in the United States, and their connections to larger national organizations provide them with important visibility and continuity in their communities (Andrews and Edwards 2005; McCarthy 2005). Despite their importance and their distinctive organizational characteristics, surprisingly little research focuses on why some civic associations work better than others.

To develop a theoretical framework for conceptualizing and explaining effectiveness in civic associations, we draw upon-and challenge-research by social movement and organization scholars. Our conception of organizational effectiveness builds on the insights of organization scholars who emphasize the value of multidimensional frameworks. However, given the differences between civic associations and the cases that organization scholars typically study, scholars need different kinds of measures, several of which we develop in this article. To social movement studies, we contribute to the ongoing interest in advocacy organizations, volunteer participation, and movement consequences. Movement scholars have developed increasingly sophisticated analyses of the ways that movements shape institutional change. But they have paid insufficient attention to the internal mobilization of voluntary effort, the structure of decision making, and the role of leadership. We thus extend recent attention to the policy impact of movements to a broader examination of organizational effectiveness at developing leaders, mobilizing participation, and gaining recognition in the public arena. We argue that while political context and the availability of financial and human resources matter, their effect is more modest than many would expect and is often mediated by organizational and leadership factors.

To discern the sources of effectiveness, we compare the differential performance of local groups in a major national environmental organization, the Sierra Club. Our study allows us to assess competing explanations for organizational effectiveness with comprehensive data from the Sierra Club's 62 state or regional chapters and 343 local groups. We examine variation in public recognition, member engagement, and leader 
American Journal of Sociology

development and assess the extent to which available resources, favorable civic and political context, and organizational characteristics and practices shape the effectiveness attained by local civic associations.

\section{EFFECTIVENESS IN CIVIC ASSOCIATIONS}

We begin by bringing together the work of organization and social movement scholars to develop a multidimensional framework for studying civic associations. We link scholarship that has been dispersed across and even within these areas, such as leadership development and effectiveness in organizational studies and participation, political impacts, and leadership in social movement studies. We focus explicitly on civic associations rather than related and sometimes overlapping organizational types such as interest groups and social movement organizations. By referring to civic associations, we highlight members and self-governance as defining organizational characteristics, which could be considered scope conditions for the claims and analysis we present.

Our work builds on a long tradition of theory and research on effectiveness in organization studies. Over the past three decades, scholars shifted from simple "goal attainment models" to more complex multidimensional frameworks (Webb 1974; Pennings 1976; Kanter and Brinkerhoff 1981), and they have increasingly recognized that effectiveness has different meanings for different types of organizations operating in different environments and with different purposes (Knoke and Prensky 1984; Cameron 1986; Herman and Renz 2004). However, because research has primarily focused on bureaucratic goods and services-providing organizations, students of civic associations must develop multidimensional effectiveness models that address their distinctive qualities.

Although social movement scholars rarely use the language of organizational effectiveness, similar theoretical and methodological debates have taken place around the concepts of success, influence, and impact, with a similar move toward a multidimensional approach (Giugni 1998; Amenta and Young 1999; Andrews 2001). Although most attention has focused on political or policy impacts of movements, this scholarship provides an important foundation for our analysis (Andrews 1997; Ganz 2000; McCammon et al. 2001; Soule and King 2006). ${ }^{2}$ In this body of

\footnotetext{
${ }^{2}$ For recent efforts to examine movement consequences in the context of organization scholarship, see Schneiberg and Soule (2005), Vogus and Davis (2005), and Haveman, Rao, and Paruchuri (2007). A small number of studies examine differential levels of participation across movement organizations or interest groups (e.g., McCarthy and Wolfson 1996), but most focus on individuals, thus privileging "demand"-side factors with little attention to the organizational factors that may contribute to differential participation across organizations (Jordan and Maloney 1998).
} 
research, the shift toward a multidimensional framework has been driven by insights that movement impact varies depending on the institutional arena (e.g., courts vs. legislatures) and stages in the policy process (e.g., agenda setting vs. policy enactment) (Burstein, Einwohner, and Hollander 1995; Andrews 2001; Amenta, Caren, and Olasky 2005a; Soule and King 2006). Just as important, recent efforts to examine the relationship of movement strategy to movement consequences opens new questions related to the role of leadership in strategizing (Ganz 2000; Martin 2008; McCammon et al. 2008). Finally, recent calls for attention to movement leaders and the more enduring interest in participation and recruitment provide opportunities for developing a broader conception of organizational effectiveness (Aminzade, Goldstone, and Perry 2001; Morris and Staggenborg 2004).

Our understanding of why some civic associations are more effective than others remains limited, particularly with respect to that which makes them uniquely civic: work that depends on voluntary participation, decentralized decision making, voluntary elected leaders, and the goal of public voice. These characteristics require leadership with little or no access to means of coercive compliance as in employee-based organizations. In a classic theoretical treatment of political organizations, Wilson argues that "authority is uncertain and leadership is precarious. Because the association is voluntary, its chief officer has neither the effective power nor the acknowledged right to coerce the members - they are, after all, members and not employees." At the same time, the "demands of the office are great" because leaders must "combine the executive task of maintaining the organization with the leadership task of defining and advancing its objectives" (Wilson 1973, pp. 215-16). Because organizational outputs depend on the efficacy of decentralized local and state units, the demand for effective leadership is felt at all levels, especially at the local level. This is unlike command and control organizations in which the greatest demand for leadership is at the very top of the hierarchy. In the 750,000 member Sierra Club, for example, its 343 local groups and 62 chapters must recruit, train, and support people who can serve in approximately 12,500 leadership posts, of which 10,000 are local—essentially one out of every 57 members must be developed as a leader. Organizational efficacy thus requires a major commitment to leadership development.

We develop a multidimensional approach to studying organizational effectiveness based on the distinct objectives of civic associations, the unique challenge of decentralized governance by elected citizen leaders, and the voluntary nature of member participation: (1) public recognition, (2) member engagement, and (3) leader development. Public recognition refers to the extent to which the organization is called upon to represent its constituency by decision makers, the media, and the public. Member 
American Journal of Sociology

engagement is the degree to which the organization generates participation by members in voluntary group activities. Member engagement can create organizational capacity (individual skills, social relationships, shared practices, and economic assets that sustain the organization over time) and influence participants and, through them, the broader community. By leader development, we mean the extent to which the organization enhances the skills of its volunteer leaders. Importantly, we find that groups vary widely on all three dimensions.

This approach has three key strengths. First, it is multidimensional, recognizing that civic associations are voluntary organizations that seek to be heard in the public arena, to engage their members in active participation, and to develop voluntary leadership equipped to govern. Second, our approach considers outcomes that simultaneously achieve desired goals and create internal capacity. In other words, just as for-profit firms simultaneously seek to generate profit and build financial equity to pursue long-term objectives, civic associations seek to make themselves heard while, at the same time, enhancing the capacity of their organization, their membership, and their leaders. Finally, our measures of effectiveness are comparable across organizations because we focus on organizational viability rather than on the success or failure of a particular campaign or project. We can thus compare organizations even if they differ on the substance of the priorities or issues they pursue.

Public recognition.-Civic associations offer members the opportunity to make their combined voices heard in the public arena, whether or not they prevail in one particular matter or another. Their viewpoint can enter public debate most consistently and effectively when they can secure ongoing recognition by authorities in their community, the public media, and the public in general (Gamson 1990). Recognition is obtained if an organization comes to be regarded as an authoritative advocate by political elites, a respected source for information and analysis in public debate, and widely known by the general public.

The scholarship on social movements and interest groups includes a long-established distinction between "recognition" and (public or policy) "influence." For example, Gamson (1990) distinguished between "acceptance" (when a group attains standing and access) and "new advantages" (when a group has a direct impact on securing new benefits to its constituency). Political scientists routinely make a similar distinction between "access" and "policy influence" (Smith 1995; Baumgartner and Leech 1998). We build on this distinction and a longer tradition of democratic theory that runs through much contemporary scholarship on social movements and interest groups to argue that civic associations provide a key mechanism through which citizens exercise voice by combining together to 
make claims in the public arena. Although recognition does not guarantee influence, it is an important pathway for the exercise of public influence.

How do we know when a civic association has public recognition? Public recognition operates via formal and informal mechanisms through which other actors seek out a group's participation and input. Do public leaders consult with the group or its members on issues that affect its interests? Do political leaders seek its endorsement? Do members of the local community view it as an authoritative voice on public concerns? Do the media turn to it as a trustworthy spokesperson? In other words, do key actors pay attention to the civic association, its leaders, and its claims? While influence may be elusive, evidence concerning the recognition that groups attain is much more readily available. Organizational leaders are able to evaluate the public recognition that their organization gains because they do or do not receive coverage in their local media, do or do not get consulted by local officials, and do or do not get requests by candidates for the organization's endorsement.

Member engagement.-Civic associations seek to involve members in their activities both as an end itself and as the way the organization creates its capacity for achieving public purposes. Since the 1980s, many civic associations have employed extensive direct marketing to recruit and sustain membership (Shaiko 1999). In these cases, membership is not generated by the local organizations and their leaders. Instead, most members receive newsletters, action alerts, and financial appeals from national organizations while having no direct, face-to-face contact with the local organizational affiliate or with each other. Activities that involve face-toface engagement and collaboration, however, create greater organizational capacity. Active membership participation not only deepens the experience of the individual and enhances the capacity of the organization but can extend its influence within the community by engaging a broader segment of the community in organizational activities (Knoke 1990b). Members who participate in group deliberations are also more likely to commit to the outcome of that deliberation, making success more likely (Black and Gregersen 1997). Through face-to-face interaction, experiences of reciprocity, and norms of trust, participation in organizational activities can also generate social capital within the group and in the broader community (Stolle 1998; Putnam 2000). To assess member engagement, we thus focus on the extent to which members participate actively in the collective work of an organization.

Leader development.-Because they rely on volunteer leadership, civic associations must both develop the capacity of current leadership and develop new leadership on an ongoing basis (Day 2001; Hackman 2002; Morris and Staggenborg 2004; Campbell 2005). Leaders play key roles in mobilizing others to devise and implement organizational strategy. Be- 
American Journal of Sociology

cause of their decentralized structure, tasks at every level of the organization require motivating people to work together, dealing strategically with dynamic and changing contexts, and adapting to the novel and challenging circumstances that accompany the work of advocacy. Civic objectives are often more diffuse than those of goods and services-producing firms; thus, civic association leaders must define and build support for goals as they mobilize members to take part in group efforts. In a voluntary civic association, leaders must do this work without the authority to require compliance that is available to leaders of public, nonprofit, and for-profit firms whose paid employees produce their goods and services - and without the opportunity for professional development that employers can provide. At the same time, civic associations do serve as "schools of democracy" by developing community leaders who are skilled, motivated, and effective, which is one of the most important contributions the organization can make to public life. We conceptualize leader development as the extent to which an organization enhances the skills of its leaders. This includes the relational, motivational, strategic, and executive skills required to engage participants, delegate responsibilities, conduct meetings, manage decision making, and enact accountability (Ganz 2009).

So far, we have focused on the ways that public recognition, member engagement, and leader development advance an organization's purposes. Public recognition advances an organization's goals and stimulates further contributions of time, energy, and money; engaged members contribute time, build solidarity, and enhance an organization's legitimacy; and leaders make the organizations work. Civic associations also have the potential to produce broader public goods that are critical for civil society and democracy. Through the exercise of collective voice, civic associations introduce important concerns into public discourse and policy, engaged members develop trust and learn valuable civic skills, and skilled organizational leaders become community leaders beyond the organization itself.

\section{EXPLAINING DIFFERENTIAL EFFECTIVENESS}

What explains why some civic associations are more effective than others? Broadly, we distinguish between arguments that emphasize factors external to the organization and those that emphasize the experience, commitment, and practices of actors internal to the organization. Scholars emphasizing external factors focus on either the civic and political context (such as the availability of allies, the strength of opponents, and political opportunities) or the availability of financial and human resources that enhance the likelihood of success (Jenkins and Perrow 1977; Goldstone 1980; Kitschelt 1986; McCarthy et al. 1988; Tarrow 1998). In the broader 
Civic Associations That Work

organizations literature, a parallel can be drawn to arguments that organizational environments shape the viability and performance of organizational units (Lieberson and O'Connor 1972; Salancik and Pfeffer 1977). An alternative line of argument emphasizes the ways that organizational practices and characteristics explain effectiveness (Wilson 1973; Gamson 1990; Andrews 2004; Ganz 2004). This perspective can be extended to include the role of leaders, and some scholars argue that leaders' decision processes and choices critically influence organizational effectiveness, although their analyses are usually based on single-case studies rather than large- $N$ studies of comparable organizational units (Burns 1978; Ganz 2000; Barker, Johnson, and Lavalette 2001; Morris and Staggenborg 2004).

Explanations that focus on external factors recognize that civic associations, like all organizations, operate in broader environments that shape their viability, structure, operations, and possible impacts (Yuchtman and Seashore 1967; Aldrich 1999; Scott 2002). The most salient factors for civic associations are the political and civic context-whether an organization works in a politically supportive environment and whether an organization operates in a community with a high density of civic organizations (Eisinger 1973; McCarthy et al. 1988; Tarrow 1998; Swaminathan and Wade 2001; Meyer 2004; Campbell 2005; Greve, Pozner, and Rao 2006).

The second set of explanatory factors considers available organizational resources. The impact of resources on the founding and survival of movement organizations is well established in the organization and movement literatures (Walker 1991; Minkoff 1993; Edwards and Marullo 1995; Cress and Snow 1996; Edwards and McCarthy 2004). For example, Minkoff (1993) found that the number of individual members reduced the likelihood of disbanding for women's and racial-ethnic organizations in the United States from 1955 to 1985, and Cress and Snow (1996) found that material resources increased the viability of local homeless organizations in U.S. cities. In a subsequent paper, Cress and Snow (2000) showed that viable organizations were critical for attaining significant changes in what they call representation, rights, and relief for the homeless in U.S. cities. Other studies find that the presence of local organizations, greater numbers of members, and financial resources can increase the likelihood of collective action and organizational effectiveness, typically conceptualized as political or policy impact (Andrews 2001; Jenkins, Jacobs, and Agnone 2003; Amenta et al. 2005a; King and Soule 2007).

Crucial resources for civic associations are the amount of revenue and the number of members. Funds may signal organizational strength, and they can be deployed to support various efforts, from major public programs to training and other capacity-building projects. Organizations with more members have a greater pool of possible participants, and, like 
American Journal of Sociology

financial resources, larger numbers of members may signal broader legitimacy for a group and its claims.

Overall, we argue that context and resource inputs are important factors in explaining the differential effectiveness of civic associations. However, their contributions are partial and indirect, and scholars have been relatively silent on the question of how organizational contexts and resources can enhance effectiveness. We can increase our explanatory power and pinpoint the organizational and leadership mechanisms through which voluntary civic associations become effective by focusing on how leaders organize themselves and the activities they carry out to enhance their capacity and achieve public purposes. To have any bearing on organizational effectiveness, a favorable political and civic context or abundant resources must be recognized and engaged strategically by organizational leaders in ways that contribute to the accomplishment of public recognition, member engagement, and leader development (Gamson and Meyer 1996; Kurzman 1996; Goodwin and Jasper 1999; Ganz 2000; McAdam, Tarrow, and Tilly 2001; Campbell 2005).

Thus, to explain variation in the effectiveness of civic associations, we examine the extent of their active leadership, their capacity to collaborate with each other, and their ability to translate resources into outputs. Our framework consists of four interrelated elements: (1) the number of core activists, (2) the extent to which they work interdependently, (3) activities that enhance organizational capacity, and (4) their activities that achieve public purposes.

Figure 1 provides a schematic overview of the prevailing context and resources model and our leadership and organizational practices model to highlight the key points of our framework. Civic associations must meet the following conditions to achieve effectiveness in public recognition, member engagement, and leader development. First, they require a critical mass of highly committed activists. Second, elected leaders must work as an interdependent team, and, third, they must turn their resources into outputs. Civic associations must be generative-in the sense that even as they deploy their resources in current activity, they must mobilize new capacity to avoid decline. As we show in figure 1, we expect that the impact of available resources and civic and political context is indirect and mediated by organizational practices, and we expect that the effect of core activists and team leadership operates at least in part through the strength of an organization's support and program activity.

Our expectations vary across the three outcomes of leader development, member engagement, and public recognition. Most important, these outcomes differ in the extent to which they are under the control of the organization itself. Thus, we would expect that civic and political context has the strongest effects on public recognition, followed by member en- 
Civic Associations That Work
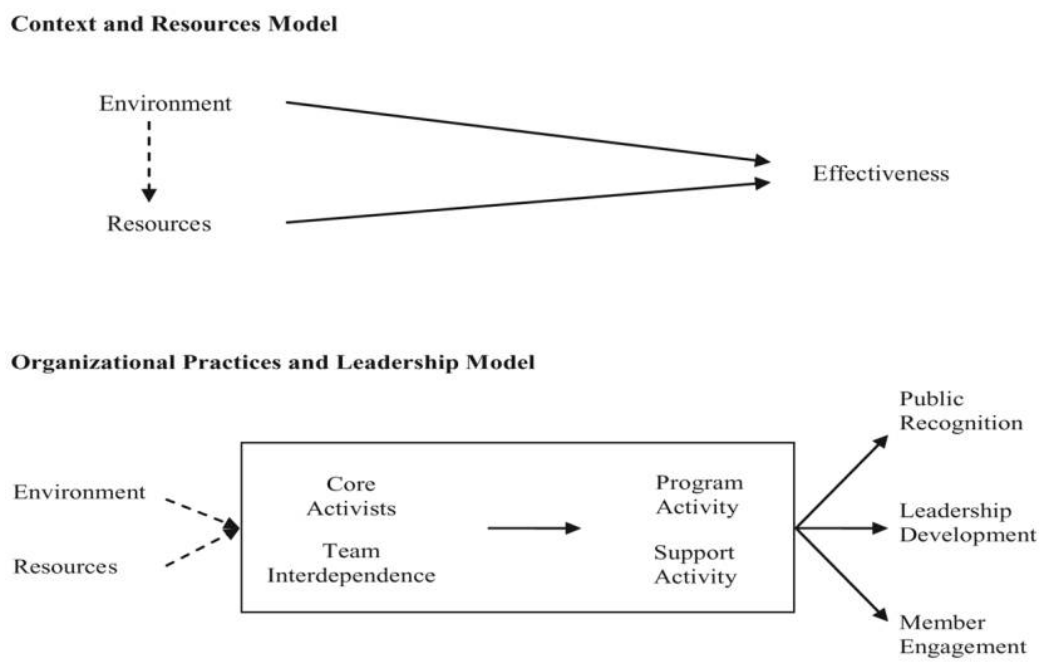

FIG. 1.—Organizational effectiveness models

gagement, then leader development. As an outcome, leader development is most insulated from the broader civic and political context and the resources that organizations receive. By contrast, public recognition is conferred by others in the community and is more likely to be influenced by the environment. The fact that movement scholars have focused more on the political consequences of movements sheds some light on the disproportionate attention to organizational environments and preexisting resources in our explanations. Yet, even for outcomes that are most susceptible to contextual factors, we expect leadership and organizational factors to influence these outcomes as well. Contextual factors, no doubt, constrain organizational actors, but civic associations have latitude to pursue varying strategies. Similarly, although the importance of resources is crucial, organizational actors make choices about how to deploy those resources and for which goals. Thus, for all three outcomes, we expect leadership and organizational practices to be important explanatory factors.

Before moving forward to describe these elements of our explanatory framework, we note that our analysis gives limited consideration to organizational structure. This is because our sample shows relatively minimal variation on common dimensions of organizational structure such as centralization or bureaucratization. In addition, the decentralized character of the Sierra Club's local organizations and the diversity of goals that organizations may pursue make groups particularly vulnerable to variation in the quality of local leadership-something that might vary far less if the structure were more centralized. However, these character- 
American Journal of Sociology

istics make Sierra Club groups typical of many other local voluntary associations as well as other task groups and work teams.

Core activists.-Highly committed activists play a critical role in volunteer-led organizations (McCarthy and Wolfson 1996; Ganz 2000; Smith 2000; Andrews 2004). They coordinate other volunteers unable to make the same time commitment, motivate others to participate, and provide administrative support for the organization. For example, McCarthy and Wolfson (1996) found that leader hours positively predicted membership size in local anti-drunk-driving groups. We distinguish between core activists, who are defined by their commitment, and leaders, who are defined by holding titled positions in an organization. Organizations with greater numbers of core activists are better equipped and more likely to carry out more diverse and viable programs.

Leadership team interdependence.-Civic associations whose leaders work as a team benefit from a quality of strategizing and implementation that will yield greater organizational effectiveness. Our claim builds on a long-standing focus in organization studies in which team design is found to affect group performance (Thomas 1957; Miller and Hamblin 1963; Mesch et al. 1988; Mitchell and Silver 1990; Wageman 1995, 2000). Yet, this line of research has not informed social movement or interest group scholarship despite calls for closer attention to deliberation, decision making, and strategy (Polletta 2002; Barakso 2004; Jasper 2004; Minkoff and McCarthy 2005). Unlike organizational leaders who work as a set of committed individuals, each of whom pursues his or her own distinctive agenda and draws upon organizational resources to do so, an interdependent leadership team focuses on achieving a common purpose, organizes tasks interdependently so as to take full advantage of individual resources, and establishes clear norms with respect to decision making, commitment, and sharing information. Its membership is bounded, stable, and includes individuals with an appropriate diversity of skills (Hackman 2002). ${ }^{3}$ Thus, we ask whether effectiveness is enhanced for organizations governed by leadership with greater leadership team interdependence.

Fund-raising and support activity.-Organizations that devote resources to enhancing their capacity will be more effective. This likely occurs indirectly by increasing the breadth and quality of program activity. We

${ }^{3}$ This concept is distinct from a focus on leadership or management styles. In addition, leadership team interdependence is related but distinct from the concept of group cohesion. In work settings, group cohesion may be counterproductive when tasks can be better accomplished individually. However, because civic associations work in dynamic environments, interdependence is more likely to enhance effectiveness. Because individuals spend limited time in their task groups (as compared to work settings), civic associations are more likely to suffer from too little rather than excessive interdependence and cohesion. 
Civic Associations That Work

examine multiple forms of capacity-building activities. One critical form of support is mobilizing local financial resources. Groups rely primarily on special events and sales of Sierra Club calendars to generate revenue; these activities require reaching out to members and the broader community, which may indirectly facilitate participation in the organization. Moreover, leaders who organize local fund-raising activity build capacity and skills. Support activities also include engaging new members, developing leadership through training and retreats, and organizing events to build solidarity and community. Finally, organizations that cultivate working relationships with allies in their communities should be more likely to achieve public recognition, recruit participants, and develop leaders (Galaskiewicz 1985; Uzzi 1996; Diani and McAdam 2003).

Program activity.-Finally, we consider the quantity and range of public activities that groups undertake, expecting that groups with more vibrant activity will be more effective in securing public recognition, member engagement, and leader development. Program activities can take many forms, including educational events, lobbying, writing reports or press releases, endorsing candidates, holding demonstrations, and organizing social or recreational events. Program activity serves as a kind of intermediate outcome, and, as we noted above, some studies treat activity as an indicator of organizational effectiveness. However, we distinguish between program activity and the outcomes that program activity can help to generate.

\section{THE SIERRA CLUB: A COMPARATIVE CASE STUDY}

We examine organizational effectiveness through a study of the local organizational units of the Sierra Club and highlight relevant aspects of the organization's history, structure, and operations. We describe the strengths of the Sierra Club as a case for studying local civic associations and the logic of our research design. ${ }^{4}$

\section{Historical and Organizational Overview}

The Sierra Club, one of the leading national environmental organizations, is based in San Francisco, with another major office in Washington, D.C., and 27 regional offices throughout the United States. Although founded in 1892, the Sierra Club grew in three distinct waves after World War II. By the end of the 1960s, it had grown from 6 California chapters to

\footnotetext{
${ }^{4}$ Although the Sierra Club is well-studied, past research has focused on the national organization, leaders, and campaigns rather than on its local leadership and organization (Devall 1970; Cohen 1988; Dunlap and Mertig 1992; Mundo 1992; Snow 1992; Gottlieb 1993; Shaiko 1999; Brulle 2000).
} 
American Journal of Sociology

32 chapters spread across the country. During the 1970s, local groups grew from just 3 to 174. Finally, during the 1980s, the Sierra Club grew from 181,000 to 600,000 members and reached 750,000 members, 62 chapters, and 343 groups by 2003 .

The national organization is governed by a 15 -person board of directors elected by the membership at large through mail-in ballots. The national board conducts organizational business through seven governance committees and numerous subcommittees, a committee structure that both the groups and chapters emulate. The national organization is what Shaiko (1999, p. 44) calls a "full-service public interest organization" that pursues a wide range of activities and goals. Although the parent organization, as a 501(c)(4), can endorse national candidates and engage in electoral activities, the national Sierra Club conducts its business through a variety of related entities that include the Sierra Club Foundation, a 501(c)(3).

The Sierra Club's 62 chapters are divided roughly into one chapter per state. The main exception is California, where there are 12 chapters plus a single state-level lobbying organization. Local groups are each affiliated with a chapter. Each chapter is governed by an executive committee (ExCom) that includes representatives of each group. Local groups, in turn, are governed by their own ExCom. Both group and chapter Excoms are elected by mail-in ballots sent to members residing in their jurisdiction. The mean size of a chapter ExCom is 12.5 members, and the mean size for a group ExCom is 7.1. Figure 2 depicts this structure.

Like many other national associations since the 1980s, the Sierra Club has relied on direct-mail marketing to recruit most of its members. ${ }^{5}$ Joining the organization entails no further commitments to the organization, such as participating in meetings or organizational governance. All members are assigned to a local group and chapter based on their residence, and most have no face-to-face interaction with their group or chapter (Mundo 1992; Shaiko 1999). However, compared to other major environmental organizations, the Sierra Club has especially high levels of participation. One survey conducted in 1978 found that $10 \%$ of Sierra Club members considered themselves active in their groups, and $15 \%$ reported participating in an outings activity (Shaiko 1999). Approximately $20 \%$ of members participated in the highly contested 2004 election for the national board. More important for our study is the fact that there is significant variation among groups that may be shaped by local leadership, organization, resources, or context.

Membership dues flow directly from individuals to the national organization, and a portion of the dues from members in their area goes to

${ }^{5}$ Members in the Sierra Club are individuals or couples who pay annual dues; individual dues were $\$ 39$ in 2003. 
Civic Associations That Work

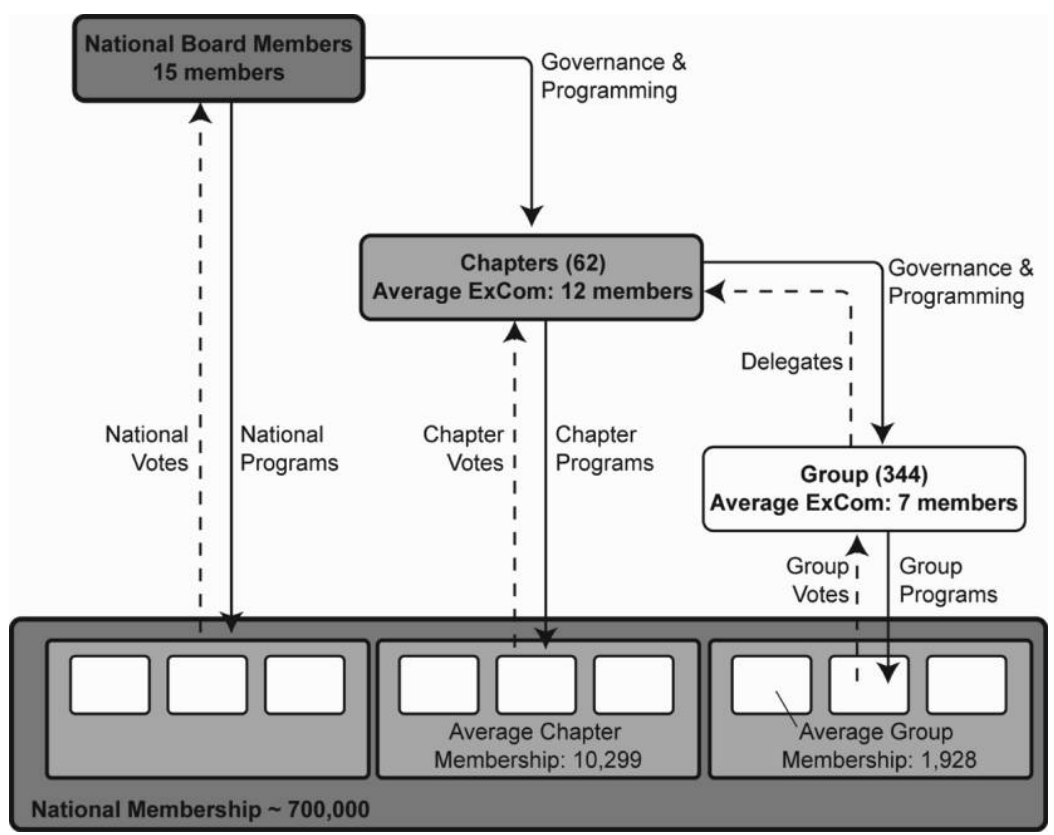

FIG. 2.-Structure of the Sierra Club's volunteer leadership

chapters. ${ }^{6}$ Chapters may choose whether and under what conditions to distribute funds to their local groups. Chapters and groups also engage in local fund-raising to support their activities and projects. The Sierra Club distinguishes its programs as conservation (e.g., lobbying, public education), outings (e.g., hiking, trail maintenance), electoral activities (e.g., endorsing candidates), and efforts intended to strengthen the organization itself (e.g., training, recruitment, fund-raising).

Strengths of the Sierra Club as a Case Study

Key qualities that underscore the Sierra Club's strength as a case study include its organizational structure, visibility, relationship to the environmental movement, and openness to academic research. We argued earlier that civic associations are characterized by voluntary participation, selfgovernance through elected leadership, and the pursuit of public purposes.

${ }^{6}$ In 2002, dues from regular and life members constituted $28.6 \%$ of the Sierra Club's revenue. This amount is greater than any of the other national environmental organizations for which there are comparable data, such as the National Wildlife Federation; National Audubon Society; Ducks Unlimited; Center for Health, Environment and Justice; Earth Island Institute; and the Rainforest Action Network (Bosso 2005). 
American Journal of Sociology

On these dimensions, the Sierra Club exemplifies contemporary civic associations. In addition, the Sierra Club is an important kind of civic association through its federated organizational form. This structure holds particular interest to scholars and practitioners because of its potential to integrate local action in a national framework (Oster 1996; Nonprofit Sector Strategy Group 2000; Skocpol et al. 2000; McCarthy 2005). Historically, many associations developed a multitiered structure as a way to combine local action with national purpose, a structure that continues to be used by influential contemporary organizations such as the League of Women Voters, NAACP, and the National Organization for Women (McCarthy 2005).

The Sierra Club's status as a major environmental organization increases the visibility and relevance of our findings. Amenta, Caren, and Olasky (2005b) found that the Sierra Club was one of the 10 most covered social movement organizations in the New York Times and Washington Post during the 1970s, 1980s, and 1990s, gaining far more coverage than any other conservation or environmental organization. Environmentalism and the Sierra Club exemplify many of the characteristics of contemporary movements that include reliance on direct membership recruitment, the relative affluence of movement supporters, the use of routine or nondisruptive tactics, and the centrality of postmaterial values to their mission (Inglehart 1990; Meyer and Tarrow 1998; Berry 1999; Putnam 2000; Skocpol 2003). Even though the Sierra Club is not representative of national environmental organizations or the movement as a whole, it has played and continues to play a critical role in the broader movement.

Finally, the Sierra Club is unusually open to academic inquiry. In our case, the opportunity to study the Sierra Club with the cooperation of its volunteer and staff leadership permitted a much richer understanding than would be the case with fragmentary or indirect access. Sierra Club leaders facilitated this project by providing access to organizational records, encouraging participation by local leaders, and implementing our survey of local leaders, thereby enriching the breadth and quality of the data.

\section{Comparative Case Study}

Our study combines the strengths of a single case study and a multiorganizational study through systematic comparisons across numerous local units. Our research follows an important tradition of single-organization studies (Selznick 1949; Lipset, Trow, and Coleman 1956; Michels 1959; Zald 1970; Kanter 1977). A major strength of these studies is their ability to delve deeply into the workings of one of a broader class of organizations to discern the key mechanisms at work. In addition, we are able to hold the organizational context constant to conduct a cross-sectional analysis 
Civic Associations That Work

of variation in units of the larger organization (Webb 1974; Pennings 1976; Hammer and Wazeter 1993; McCarthy and Wolfson 1996; Edwards and McCarthy 2004). By contrast, studies of heterogeneous organizational populations are poorly equipped to examine effectiveness because of the difficulties in establishing comparable outcomes across diverse organizations (Schlozman and Tierney 1986; Knoke 1990a; Walker 1991).

\section{DATA COLLECTION AND MEASUREMENT}

We began this study in the summer of 2003 following discussions with Sierra Club leaders concerned about the unrealized potential of their local organizations and members. Our project advances theoretical questions concerning organizations and social movements while addressing the strategic dilemmas that the Sierra Club and numerous other civic associations face.

\section{Data Collection}

The unit of analysis for our larger project is each group or chapter, with a particular focus on the elected executive committee (ExCom). All of the Sierra Club's U.S. groups and chapters were included, except for those that were in reorganization in September 2003. ${ }^{7}$ For this article, we present data only on groups because they are more numerous and more fully rely on volunteer leadership. We describe each of our four data sources below and the process we used for collecting the data.

Structured interviews with ExCom chairs focusing on organizational structure, activities, and efficacy.-From October 2003 to January 2004, we conducted 50-minute telephone interviews with 368 group and chapter executive committee chairs focusing on questions of organizational structure, leader and member participation, activities, networks, practices, community assessments, and effectiveness. The Survey Research Center at the University of California, Berkeley, conducted these interviews, and we achieved a $90.6 \%$ response rate.

Written surveys with executive committee members on background, leadership, and organizational practices.-Our 15-page ExCom Leader Survey (ELS) was completed by 1,624 ExCom members prior to local meetings to assess organizational practices led by volunteer facilitators conducted between October 2003 and February 2004. Within the ExComs that held a self-assessment meeting, $68 \%$ of ExCom members completed

\footnotetext{
${ }^{7}$ Reorganization status refers to organizations that do not meet minimal organizational standards, such as the presence of an elected ExCom, and that are receiving assistance from the national organization to reestablish the organization in a community.
} 
American Journal of Sociology

the survey, as did $51 \%$ of all ExCom members. The survey includes closedended and open-ended questions on the background, leadership experience, goals, motivations, and practices of local leaders, as well as their evaluation of the practices and efficacy of their own ExCom. We use this data both to characterize individual leaders and aggregate it to assess the leadership of each group.

Secondary data available from the Sierra Club.-The Sierra Club provided us with extensive data on groups, chapters, and members, such as membership size, average tenure, leadership size and positions, financial resources, and expenditures. These indicators allow us to assess the validity of our survey measures, thereby increasing our confidence in the data collected from our survey instruments (see the methodological appendix A for details).

Secondary data on community context.-We constructed measures of demographic, economic, political, civic, and environmental characteristics of the community in which groups work from the U.S. census and other relevant sources.

\section{Effectiveness Measures}

Public recognition measure.-We evaluate recognition-or voice-by the extent to which Sierra Club leaders are called upon by authorities, the media, and the public for their support, resources, or information. We measure this based on six questions from our interview with ExCom chairs. The ExCom chairs evaluated the accuracy of a series of statements about their group where the value 1 indicates "not very accurate" and 5 is "very accurate." Question items are presented in appendix B. We aggregated items constructing a single indicator of public recognition based on the mean of all six items. The scale is highly reliable $(\alpha=.742)$ and has substantial variation (mean $=2.7 ; \mathrm{SD}=.8$ ). Descriptive statistics for public recognition and all other variables are reported in table 1.

Member engagement measure.-We measure member engagement by the degree to which members participate in group activities. Like other civic associations, Sierra Club groups have more members than participants. Member engagement can take many forms, from going on an organized hike to attending a fund-raiser; we measure the number of individuals who participate on a regular or time-to-time basis in such activities. Our measure is based on two questions asked in our phone interview with the group chair. We asked the chair to estimate the number of people who participate regularly in the activities of the group, and we asked the chair to estimate the number of people who participate from "time-to-time." Our measure is the sum of these two estimates. The average group has 37 participants, and the median is 27 . The median group 


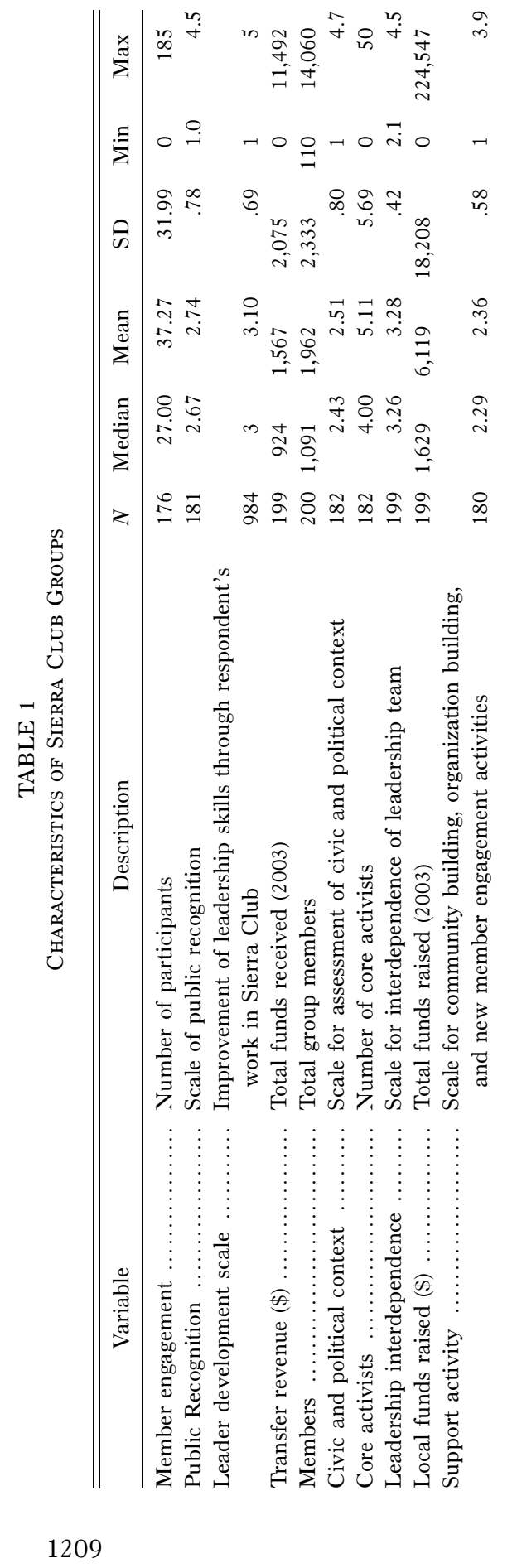




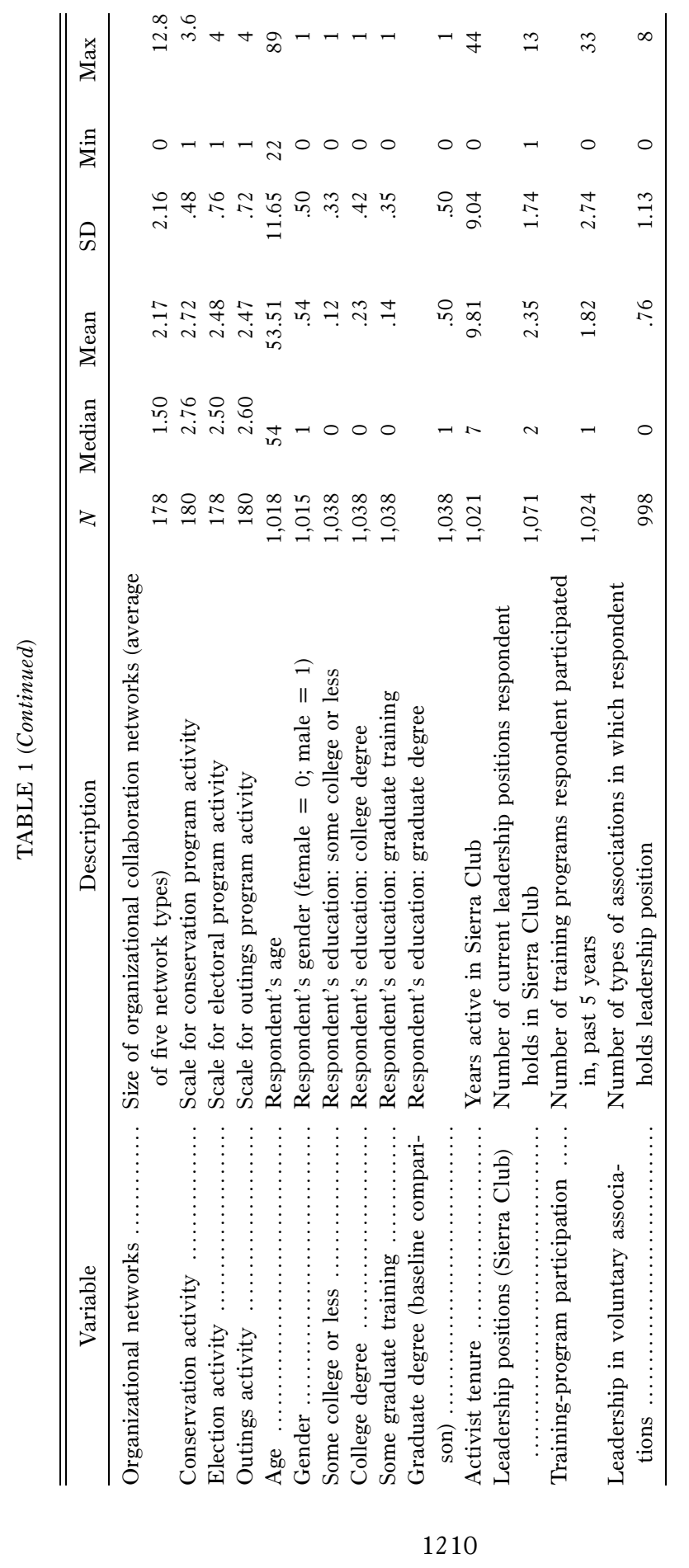


Civic Associations That Work

has 15 regular participants and 12 time-to-time participants. Although recall bias is a reasonable concern for a question like this, we note that participation is generally quite low, which should make it easier for chairs to provide valid responses. In addition, this measure is highly correlated with other measures of participation that we collected. ${ }^{8}$

Leader development measure.-We measure leader development using a 19-item scale that captures the development of skills related to carrying out tasks and working with others. Our measures are derived from surveys completed by the elected leaders serving on executive committees. In each case an individual leader assessed his or her acquisition of skills on 19 specific questions. Leaders were asked to "please indicate whether your leadership skills have improved through your service as a volunteer in the Sierra Club" on a scale from 1 (strongly disagree) to 5 (strongly agree) and whether "I am better at" relevant skills such as "delegating responsibilities to others," "managing my time," or "speaking in public." See appendix $\mathrm{C}$ for the specific items. Scale reliability is high $(\alpha=.932){ }^{9}$

\section{Context, Resource and Leadership Measures}

We measured the civic and political context using a six-item scale based on the chair's assessment of allies, opponents, and local government. We asked the chair to evaluate the accuracy of the following statements, where the value 1 indicated "very accurate," 5 was "very inaccurate," and 3 was "in the middle": (1) government in this area is generally favorable to our goals, (2) most elected officials hold positions that conflict with ours, (3) government in this area has committed substantial resources and effort toward improving environmental quality, (4) progressive groups and movements are very strong in this area, (5) the environmental movement is very strong in this area, and (6) conservative groups are very strong in this area. All items (except number 6) were reverse coded so that higher values indicate a more favorable context.

To validate this measure, we examined the civic and political context

\footnotetext{
${ }^{8}$ We asked eight questions about the number of committees and committee participants from which we constructed a summary measure of the number of members serving on committees. That measure is highly correlated with our measure of participants $(r$ $=.59 ; P<.001)$.

${ }^{9}$ On initial inspection, social desirability bias may be a concern with this measure. However, given the high levels of education and professional accomplishment that Sierra Club leaders bring to the organization, we question whether the "socially desirable" response to these questions would lead respondents to report high levels of skill learning. Skill development is measured retrospectively and in relation to volunteer service, so our measure is distinguished from a self-efficacy measure that captures an individual's confidence in her capacities.
} 


\section{American Journal of Sociology}

two other ways: (a) using objective indicators derived from external data, such as college graduates (\%), median household income, civic organizations per capita, and voting in the 2000 presidential election, and $(b)$ membership density, measured as the per capita number of Sierra Club members in a group's territory, providing an indicator of the community's receptivity to the organization..$^{10} \mathrm{We}$ found variation on all three measures, and they were all are highly correlated with one another (see our methodological appendix A for further details). These alternative measures produce similar results, and substituting them in our models does not alter our substantive conclusions. Because the chair's assessment is more highly correlated with our dependent variables, it provides the most stringent test of our argument that civic and political context should have a modest relationship once organizational factors are considered. In addition, the chair's assessment will be more sensitive to local conditions, including contingent or unique opportunities, than the available objective measures.

We measure resources with two straightforward indicators: the number of members in a group and the financial resources that a group receives from the larger organization-transfer revenue. As described above, members are assigned to a group and chapter based on residence. Membership totals were provided to us by the Sierra Club for August 2003. The median membership size for groups is 1,091 , and the mean is 1,962 . Our measure of transfer revenue was calculated from annual reports submitted by Sierra Club groups to the national organization for the 2003 fiscal year. Transfer revenue is skewed; the median is $\$ 924$, and the mean is $\$ 1,568$. We take the log of membership and transfer revenue in the analyses below.

We measure core activists based on a question from our phone interview with the ExCom chair in which we asked, "How many volunteers spend at least 5 hours per week on Sierra Club work?" The median is 4 , and the mean is 5.1 core activists for Sierra Club groups. ${ }^{11}$

To measure interdependence of the leadership team, we created a scale based on items from the ExCom Leader Survey that includes 12 questions evaluating the extent to which the ExCom has shared goals, engages in collective planning, holds one another accountable, works collaboratively,

\footnotetext{
${ }^{10}$ Population measures such as the proportion of college graduates, household income, and population size were constructed from 2000 U.S. census by matching zip codes to the boundaries of Sierra Club groups. Voting data are matched on the primary county for each group and were compiled from Polidata Demographic and Political Guides (http://www.polidata.org). Data on civic organizations were calculated using the data files from the National Center for Charitable Statistics and matching zip codes to boundaries of Sierra Club groups.

${ }^{11}$ We use the count rather than the percentage of core activists because the numbers are very small relative to the larger membership and because conceptually we are interested in the leadership capacity that core activists contribute.
} 
and has shared norms concerning expected behavior. We expect that ExComs operating as interdependent teams enhance leader development and also encourage greater member engagement and public recognition. Our measure aggregates the responses provided by individual ExCom members for each group; the interdependence scale is highly reliable $(\alpha$ $=.860)$. Specific items are listed in appendix D.

We measure the efforts to enhance organizational capacity in terms of local fund-raising, support activities, and the development of interorganizational networks. Local fund-raising is measured as the total revenue raised by the group; the median is $\$ 1,629$, and the mean is $\$ 6,119$. Like transfer funds, locally raised funds are measured for fiscal year 2003 from reports to the national organization, and we take the natural log. Support activities include efforts to develop capacity through retreats and training, build solidarity through social events, and engage new members with specific forms of outreach. ${ }^{12}$ We constructed a scale based on the chair's response to seven questions about the regularity with which the group carries out specific support activities $(\alpha=.66$; mean $=2.36$; $\mathrm{SD}=.58)$. Organizational networks are measured by combining responses to five questions in which the chair was asked to estimate the number of environmental organizations, community groups, elected officials, government agencies, and business or private sector groups that they had worked with directly in the past year on common projects.

Programs include the specific conservation, electoral, and outings activities that groups do. Conservation refers to efforts to shape the public and political agenda through activities like lobbying, holding educational events, and organizing marches or demonstrations. Electoral activities include efforts to influence elections for candidates or ballot initiatives by mobilizing voters and making endorsements. Outings are activities designed to bring people into natural settings for social, recreational, and service purposes such as hikes or trail restoration projects. Items measuring support and program activity were taken from our phone interviews; our question asked the chair to indicate "how often your group or volunteers acting on behalf of your group" have done an activity during the past 12 months. Response categories were "regularly, sometimes, rarely, or never." Activity measures are reverse coded such that higher values indicate more frequent activity. Appendix $\mathrm{E}$ also lists the program activities included in these scales. All three scales are reliable and exhibit high levels of variation. Correlation matrices for group and individual-level variables are included in appendix tables $\mathrm{F} 1$ and $\mathrm{F} 2$.

${ }^{12}$ We also measured communication, such as advertising upcoming events, but these activities are quite common and have minimal variation in our study. 
American Journal of Sociology

ANALYSIS

We first present models explaining public recognition, followed by member engagement and leader development. For each outcome, we present a comparable set of analyses beginning with a base model that considers the relationship to available financial resources, members, and the political and civic context. We then introduce dimensions of organizational practices in separate cumulative models-specifically, in model 2 we add the number of core activists, and in the following models we add leadership interdependence (model 3), locally raised funds (model 4), support activities (model 5), organizational networks (model 6), and program activities (model 7). The rationale for this sequencing is based on our expectation regarding factors that are causally prior in explaining effectiveness as illustrated in figure 1. For example, we expect that core activists play a fundamental role generating support and program activities and that support activities, in turn, play an important role in generating program activity.

We examine our expectations about the possible indirect or mediating effects in our model using formal mediation tests (Baron and Kenny 1986; Preacher and Hayes 2004). When the effect of an independent variable on a dependent variable is carried through another variable, that variable is considered a mediator. Broadly, we consider two kinds of mediation effects for public recognition that follow from our explanatory framework: (1) whether resources and context are mediated by organizational practices such as governance and (2) whether core activists and support activities are mediated by a group's program activity. ${ }^{13}$

\section{Public Recognition}

Table 2 presents ordinary least squares (OLS) regression models for public recognition. We begin with model 1 by examining the impact of membership, transfer revenue, and context on public recognition. The civic and political context has a substantial positive effect on public influence, and membership size has no discernible effect on public recognition. Surprisingly, the amount of revenue that groups receive has a negative and significant effect (only at the .10 level) on public recognition.

In model 2 we introduce the number of core activists, and this measure has a significant positive effect, and model 3 shows that team leadership

${ }^{13}$ We have tested for all other possible mediation effects between our organizational practices and leadership variables, on the one hand, and the civic and political context and available resources effects, on the other. We only discuss the statistically significant effects and the nonsignificant effects that have strong theoretical relevance. 
Civic Associations That Work

does not. Local fund-raising is not significant in model 4, but support activities do have a positive and significant effect in model 5 . Further, in model 6 we find that organizational networks enhance public recognition. Finally, model 7 shows that conservation and electoral programs have significant positive effects on public recognition, and the effects of support activities and core activists are insignificant in the full model. We note that the explanatory power of the model increases substantially from .13 to .48 when organizational factors are included along with political context. More specifically, we also note the increase in the adjusted $R$-squared from .35 in model 6 to .48 when program activity is included. The results for conservation and elections suggest that regardless of whether groups operate in favorable or hostile environments, they can exert influence by developing programs that engage the public.

One clear finding here is the substantial and robust effect of civic and political context on public recognition. This relationship persists in all models, and there is no evidence that the effect is mediated by internal organizational factors as we expected. On the other hand, it explains less than half of the variance the full model explains, when the organizational characteristics and practices are included. For public recognition, although our results support the claim that a favorable civic and political context enhances a group's ability to shape social and political change, it also underscores the fact that influence is highly dependent on what its local leaders make of the context in which they find themselves. We find evidence for the critical role of core activists in generating public recognition; this effect is independent of context and resources and persists when team leadership, fund-raising, and support activity are included. In addition, we find that program activity - especially conservation and electoral-plays a major role in shaping an organization's public recognition. However, the effect of core activists is substantially reduced in model 5 and nonsignificant in models 6 and 7 , as is support activity in model 7 . We investigate whether the effect of core activists and support activities operates in part through their indirect influence on program activity.

Baron and Kenny (1986) delineate four conditions that must be present for a variable to be a mediator: (1) the initial independent variables must be correlated with the outcome (public recognition), (2) the initial variables must be correlated with the mediator (conservation programs), (3) the mediator must affect the outcome variable, and (4) the effect of the independent variables on the outcome while controlling for the mediator should be statistically smaller than in a model without the mediator. Results in models 4 and 5 provide evidence for the first and third conditions. Bivariate correlations of conservation activity with support activities $(r=.35)$ and organizational networks $(r=.46)$ provide evidence that the second condition is present. The correlations with electoral ac- 


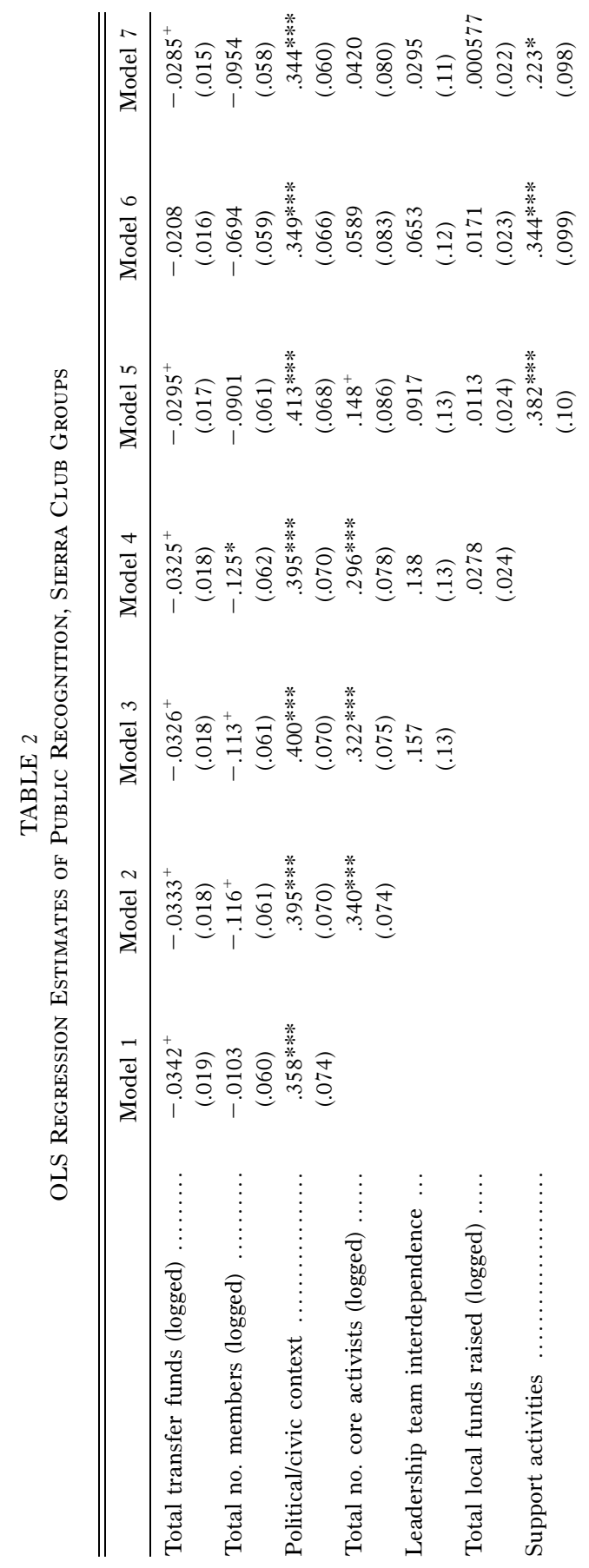

1216 


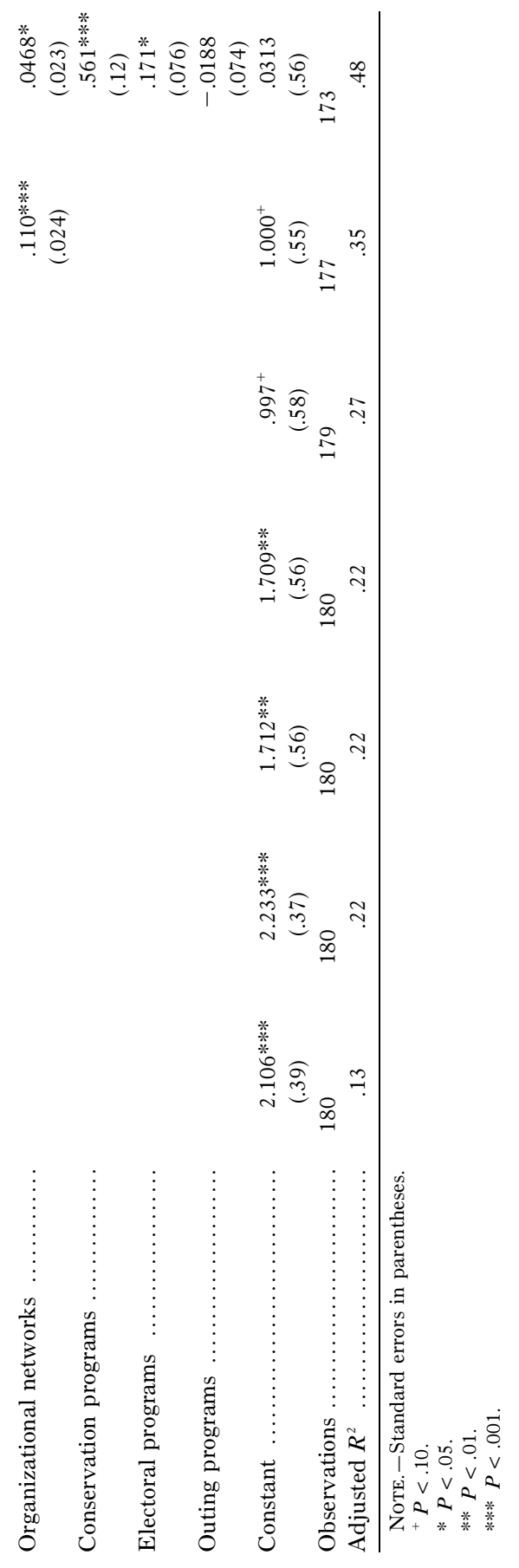

1217 
American Journal of Sociology

tivity are also significant for support activity $(r=.29)$ and organizational networks $(r=.32)$. Finally, we use Sobel tests to provide a formal test of the fourth condition that the effect of the independent variable (organizational networks or support activity) is reduced when controlling for the mediator (conservation or electoral activity). Conservation activity mediates the relationship between organizational networks $(P<.001)$ but not support activity. In addition, we find that electoral activity mediates the relationship between support activity $(P<.05)$ but not organizational networks. Overall, then, mediation tests support our claim that organizational networks and support activity have an indirect effect through their influence on an organization's program activity.

\section{Member Engagement}

Table 3 presents negative binomial regression models for the number of participants in Sierra Club groups. Negative binomial regression is appropriate for estimating models with count data and is preferable to the Poisson model when there is substantial overdispersion, as in this case (Long and Freese 2006).

Model 1 indicates that the number of members has a positive and significant effect on the number of participants, but unlike public recognition, the broader political and civic context does not affect member engagement nor does the amount of transfer revenue. This result differs from public recognition and runs counter to expectations of political opportunity theory, which would anticipate a favorable context to encourage participation. The interpretation for the number of members appears straightforward - that more members provide a large pool of potential participants.

In model 2, we find that the number of core activists has a significant and positive effect on member engagement, and this effect persists in subsequent models. We also find that the number of members is not significant. Model 3 shows that leadership team interdependence has a positive and significant effect on participation, and this effect is also robust across subsequent models. Local fund-raising has a positive and significant effect in model 4, although support activity does not in model 5. Model 6 shows that organizational networks have a modest positive effect. Finally, we find that core activists, governance, local fund-raising, conservation, and outings activity are positive and significant in model 7 .

Overall, participation is explained by the presence of committed activists, how well leaders work together as a team, and the strength of their fund-raising and program activity. When it comes to mobilizing participation, it is not surprising that more activity-both conservation and outings activity - is related to greater participation. It is important to note that, even with activity in the model, core activists continue to have an 
independent (if more muted) effect. This finding is consistent with the claim that the scope and range of activity has a strong relationship to the number of people able to commit the time and effort to leading that activity. ${ }^{14}$

We examine whether core activists mediate the relationship between the number of members and participants and whether outings program activity mediates the relationship between local fund-raising and participation. ${ }^{15}$ The presence of a significant correlation between members and core activists $(r=.38)$ alongside the results in models 1 and 2 provide evidence of the first three conditions for mediation. Results from a Sobel test $(P<.001)$ provide additional support for our interpretation that the effect of members on member engagement is indirectly operating through the number of core activists. Additionally, we find that outings program activity mediates the relationship (in part) between local fund-raising and member engagement $(r=.26$; Sobel <.001). Thus, we find that groups that undertake greater fund-raising enhance their capacity to carry out more outings program activity. Given the robust finding for leadership interdependence, these groups may also do their activities better and create an internal environment more conducive to regular participation by members.

In sum, we find that explanations of participation that focus only on context and available resources are insufficient. Civic and political context plays no apparent role. The pool of organizational members has a modest positive effect that operates mainly through the number of core activists. Financial resources transferred to the group are also insignificant, although locally generated revenue is quite important. Core activists, leadership interdependence, fund-raising, and program activity drive mobilization far more than external factors and dramatically improve our ability to explain differences in participation across Sierra Club groups. We should also underscore the result that different kinds of program activity matter for public recognition and member engagement, with recreational outings activities playing a more central role for member engagement than public recognition. This may be because outings programs typically entail clearly defined activities, in contrast to conservation and

${ }^{14}$ We conducted two sets of supplementary analyses to address possible concerns about the measurement of participants and core activists. These analyses provide very similar results and are available from the authors. First, we ran models in which we only included "regular participants" in the dependent variable to provide a more conservative estimate of member engagement. Second, we conducted analyses in which we subtracted the estimate of core activists from our measure of participants to address a possible (but unlikely) measurement error in which the chair could have doublecounted core activists as participants as well, thereby driving the relationship.

${ }^{15}$ For mediation tests, we use the natural log of the number of participants; OLS models using this measure generate comparable results to the negative binomial regression models in table 3. 


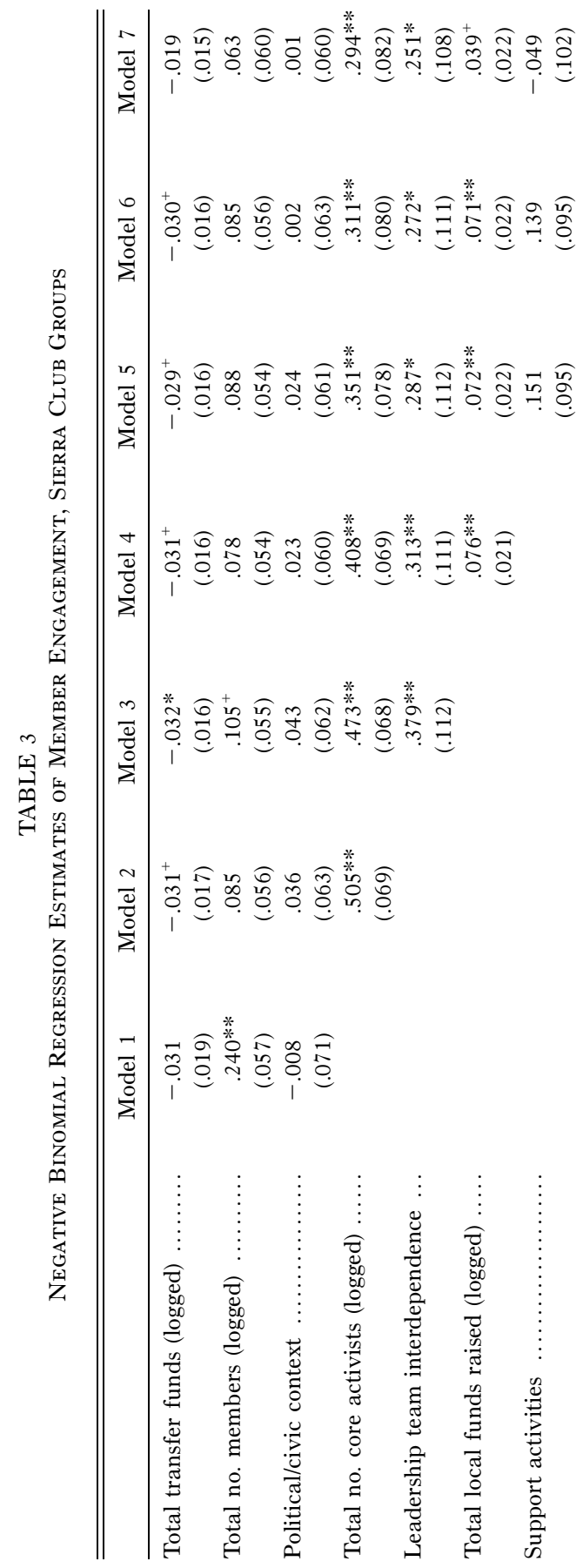

1220 


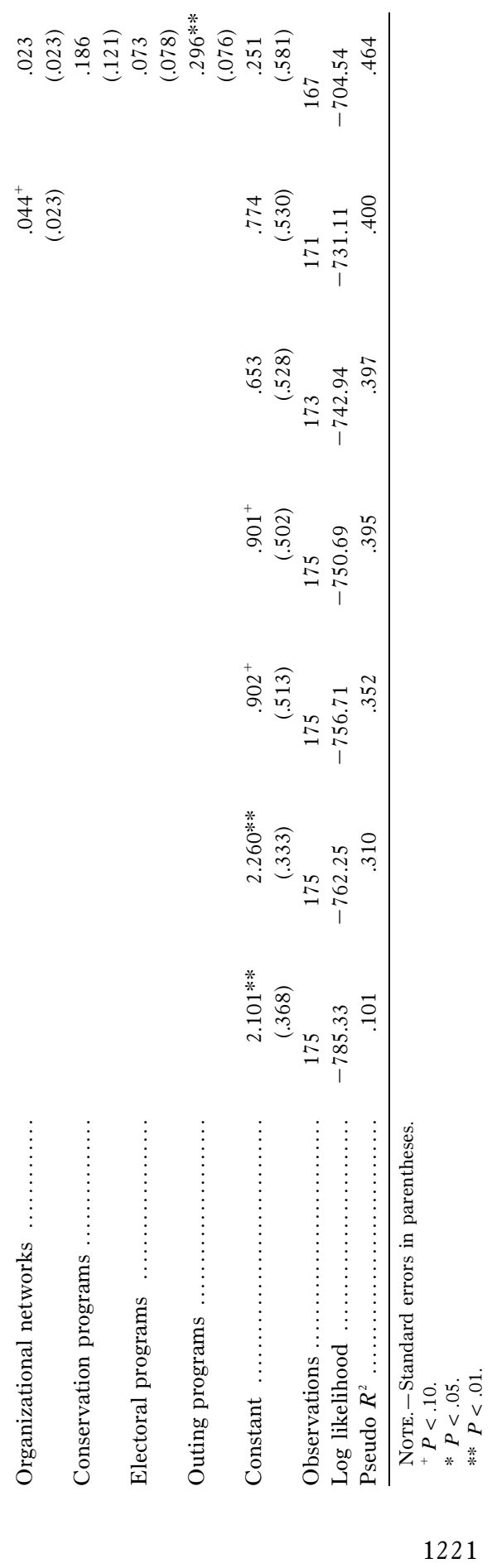


American Journal of Sociology

electoral activity, which is more episodically organized around issues and elections. Moreover, outings activities are by definition collective activities in the Sierra Club, while conservation and electoral activities can be carried out by one or a very small number of individuals. Most interesting, however, is the strong relationship between the number of core activists and the extent of group activity, especially recreational activity. This suggests that the choices leaders make about how much time to invest and where to invest it has a major impact on the levels of broader membership participation.

\section{Leader Development}

Leader development presents the greatest challenge for our analysis because elected leaders are nested in their ExComs, and leader development is a product of both individual- and group-level factors. Organizationlevel OLS models are not appropriate techniques for estimating the individual and organizational factors that contribute to leader development. Instead, we estimated an OLS model at the individual level using robust standard errors that take the nested nature of the data into consideration. We have also estimated hierarchical linear models using random intercept models that produce nearly identical results to those reported here. We prefer the OLS model because it is more comparable to the models presented above for public recognition and member engagement (see table 4).

Although we consider the same organizational factors, we begin with a base model that includes individual-level covariates. Specifically, our models include age, gender, education, activist tenure, leadership positions, training-program participation, and leadership in other types of voluntary associations. As model 1 indicates, ExCom members who are younger report less leader development, while those who have not completed a college degree report greater leader development. An individual's experience in the Sierra Club and with other voluntary associations also contributes in important ways to leader development. ExCom members who have been active longer, hold more leadership positions, have participated in more training programs, and hold leadership positions in other organizations have greater levels of leader development. In fact, much of the story regarding leader development is captured by these aspects of an individual's experience as a volunteer leader. The key organizationlevel factor that shapes leader development is the executive committee's interdependence as a leadership team as indicated in model 4.

These conclusions are consistent with our broader argument emphasizing the critical role that organizational practices play in enhancing effectiveness. Although we do find that an individual's leadership experience outside the Sierra Club enhances leader development, other indi- 
Civic Associations That Work

vidual-level factors capture important experiences within the organization that generate greater skills and, we suspect, greater commitment and efficacy. Organization-level resources and contextual factors play no meaningful role in enhancing leader development, but, as with member engagement, we find that leadership teams that create shared goals and norms and plan and execute their work collectively enhance the skill development of their members.

Comparing across our models, we find important differences across the outcomes. Our results show that certain kinds of program activity are more likely to yield public recognition while others are more consequential for member engagement. Available resources matter indirectly for member engagement, and a favorable civic and political context has considerable impact on public recognition. Yet, these factors only tell a small portion of the broader story about why some civic associations are more effective than others. Moreover, taken together, the results tell a consistent story about the importance of core activists, leadership team interdependence, and support and program activity for organizational effectiveness. Groups that have more highly committed activists, that devote time and energy to building the capacity of their organization through fund-raising and other support activities, that organize and implement strong programs to pursue their public goals, and whose leaders design work interdependently, generate greater effectiveness across quite different outcomes.

Given that we rely on cross-sectional data, our claims about the causal relationships must be treated with some care, and the basic claims will benefit from future research that includes longitudinal data. The potential threats to our interpretation vary for public recognition, member engagement, and leader development, so we consider each in turn. A major concern with public recognition and member engagement is that there may be a "feedback loop" such that groups that are highly influential in their communities and mobilize their members engage in more activity because leaders have confidence from past experience that their efforts will be efficacious. Although civic associations can engage in activity with minimal influence, there is little evidence that organizations can be influential or attract participants without developing public activity. Thus, even if past recognition enhances program activity and subsequent public recognition, the feedback loop itself was, we argue, set in motion by strong program activity. With member engagement, the relationship between core activists and participants may raise similar concerns; groups with a larger number of participants may benefit from a larger pool of people to become core activists. However, participants become engaged through activities-especially recreational and service-oriented outings-and in local volunteer organizations, these activities are the products of highly committed activists (Staggenborg 1991; McCarthy and Wolfson 1996; 


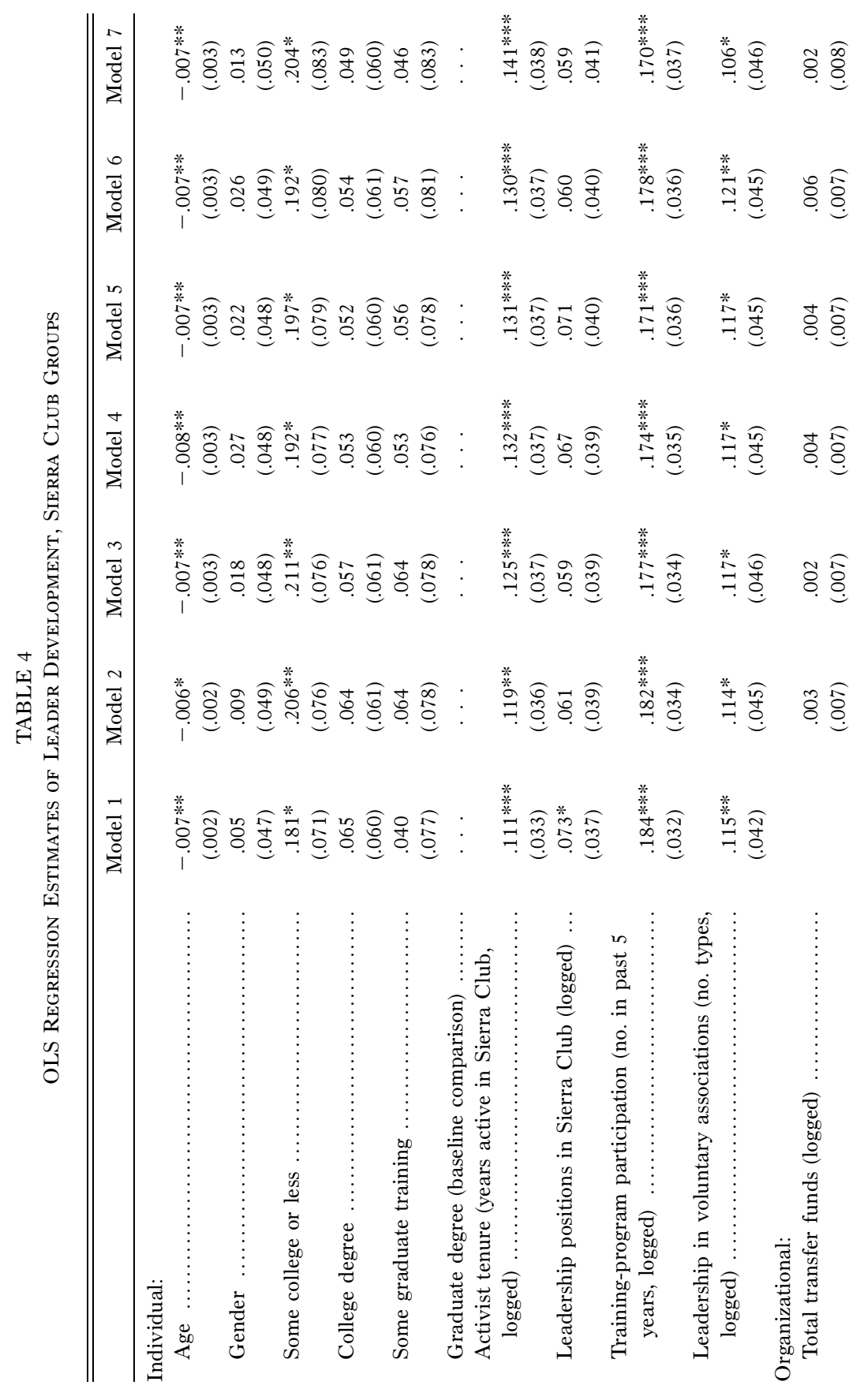




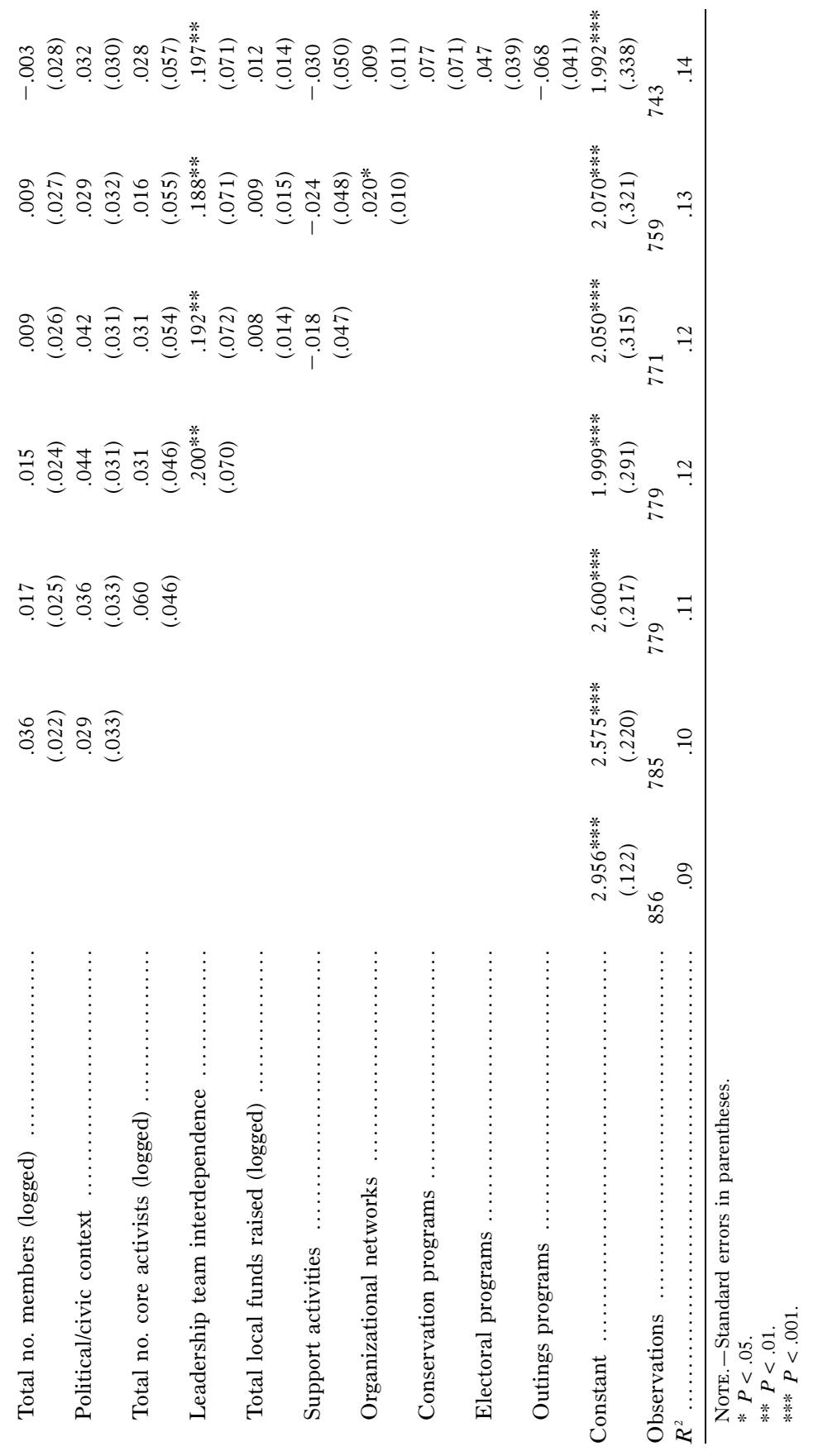


American Journal of Sociology

Morris and Staggenborg 2004). Finally, with leader development, our major finding concerns the positive impact of leadership teams on leader development. Here, the concern might be that more skilled leaders are better able to work effectively as a team. The fact that our questions about leader development concern the extent to which an individual leader's skills "have improved" mitigate some of this concern because we measure change. Overall, these concerns regarding the causal order are ones that we have attempted to handle judiciously, but we recognize that longitudinal and ethnographic methods will be needed to further test and refine the claims we make. However, we expect that the theoretical arguments advanced in this article buttressed by an important set of new findings will motivate exactly this kind of research and open a promising new domain of theory and research at the intersection of organization and movement studies.

\section{DISCUSSION AND CONCLUSIONS}

We began this article by pointing to the lack of systematic efforts to understand why some civic associations are more effective than othersa question of major significance for understanding organizations and contemporary politics. To develop our framework for studying effectiveness in civic associations, we looked to work by organizational scholars who study effectiveness in service-providing and goods-producing organizations and to social movement scholars and others who study civic associations including social movement organizations. Through this process we developed and articulated a three-tiered conception of effectiveness that sees civic association as "schools of democracy"-places where individuals learn through interaction the skills of democratic practice to pursue collective purpose. From this perspective, the accomplishment of leader development, member engagement, and public recognition are each equally important dimensions for evaluating the effectiveness of civic associations.

To explain differential patterns of effectiveness, we compared prevailing explanations. Some have argued that organizations working in more favorable civic and political contexts will be most effective. Another view contends that the availability of human or financial resources is critical. Finally, others have argued that organizational practices (reflecting the choices and efforts of leaders) influence effectiveness. Employing original data collected from several sources, we used multivariate analyses to evaluate the relationship of favorable context, available resources, and organizational leadership practices and programs to effectiveness. The political and civic context has an important impact on public recognition, 
Civic Associations That Work

but it plays no apparent role in engaging members and developing leaders. We find some support for the importance of available resources, but the effects are more modest than proponents would expect, and they are largely indirect-operating through organizational factors that we have identified. This is because available resources and context must be perceived and acted upon by leaders. Our attention to organizational practice provides greater explanatory power and helps specify the way that context and resources matter while also exerting independent effects on the effectiveness of civic associations.

In addition to presenting original findings on the effectiveness of civic associations, we hope to motivate future theoretical and empirical analyses by organizations and movement scholars. To this end, there are several limitations of our study that future scholars may move beyond. These include our reliance on cross-sectional data and the selection of organizational units from a single organization. Case studies would allow scholars to examine mechanisms through which participation influences leaders and members (Reger and Staggenborg 2006). For example, we need a much clearer understanding of why and how some groups establish and maintain stronger forms of leadership interdependence. Comparative case studies focused on leadership teams could add considerably to our understanding of this question by collecting rich ethnographic accounts of internal organizational dynamics. Longitudinal data on leadership development collected using fieldwork or repeated surveys would allow scholars to examine more effectively the ways that participation in the organization shapes individuals. With member engagement, we would also benefit from studies that include direct surveys and interviews of members to move beyond the count data presented here (Knoke 1990a; Rothenberg 1992; Leighley 1996). To measure public recognition, future studies could combine leaders' reports with reputational measures from community leaders (Hammer and Wazeter 1993; Fiorito, Jarley, and Delaney 1995).

This study of the Sierra Club's organizational effectiveness contributes to ongoing debates about the role of civic associations within sociology, political science, and organizational studies. Although a new and fruitful dialogue has begun between social movement and organization scholars, we believe that both fields will benefit from a more sustained examination of leadership and the processes within organizations to complement the macro-organizational focus that has emerged to date (McCarthy and Zald 2002; Andrews and Edwards 2004; Clemens and Minkoff 2004; Ganz et al. 2004; Armstrong 2005; Davis et al. 2005; McAdam and Scott 2005). So far, the convergence between organization and social movement scholars has emphasized the use of social movement theory to broaden the core substantive domains of organization scholars such as the spread of 
American Journal of Sociology

new organizational forms (Swaminathan and Wade 2001) and intraorganizational conflict and change in corporations (Morrill, Zald, and Rao 2003). Our study extends the dialogue the other way by developing a multidimensional framework for analyzing the effectiveness of civic associations, bringing important insights from organizational studies, including scholarship on leadership, group interdependence, and effectiveness to the study of movements. It also draws an important, but often ignored, distinction between voice-seeking, voluntary civic associations governed by local elected leaders and public, nonprofit and for-profit goods or services-producing firms with paid employees managed bureaucratically by appointed full-time managers.

Like most large, national civic associations, the Sierra Club experiences wide variation in the performance of its local organizations. Some leaders gain valuable skills and motivation through their work, while others become discouraged. Some groups engage hundreds of members in their activities, while others engage fewer than 10 members. Finally, the voice of some groups is widely recognized in some communities, contributing to public debate, influencing electoral outcomes, and shaping public policies, while the voice of other groups is more muted.

To explain this variation, many scholars would direct our attention to differences in the context within which groups operate and the resources to which they have access-factors over which organizational leaders have little influence. While our analyses show some support for these expectations, our study shows that of far greater significance, especially in voluntary associations, is the capacity that organizational leaders can develop to make the most of resources and opportunities. And while prior accounts may inform the research of those who study organizations, our account can also inform the practice of those who lead them.

\section{APPENDIX A}

Methodological Appendix

Response bias.-Overall, the response to our telephone survey and ExCom Leader Survey were remarkably high, minimizing the likelihood of significant nonresponse bias. However, we undertook a comprehensive analysis to assess possible bias in our data sets using secondary data. Since these data included information on all groups, we could examine the extent to which participating groups differed from those that did not participate on key organizational characteristics: (1) the number of individuals holding leader positions in the group, (2) the number of ExCom members, (3) the percentage of ballots returned in the 2003 national board election, (4) the number of members in the group, (5) the average leadership tenure, 
and (6) the average number of leadership positions held by each individual leader.

In evaluating our phone interviews, we compared the means of participating groups to nonparticipating groups and found no statistical difference between them on any of the six indicators. We evaluated the ExCom Leader Survey in the same way, comparing ExComs for which we had ELS data to ExComs for which we did not on the same six dimensions. We found that nonparticipating group ExComs had slightly smaller leadership cores than those that participated, although we found no difference on other dimensions, such as membership size. (Results of these analyses are available from the authors.)

Aggregation of individual data.-With our surveys of ExCom members, we are primarily interested in the collective assessment by ExCom members of their group. To determine whether groups with high rates of participation differed from those with low rates of participation, we conducted a response-bias analysis using several measures of demography and leadership commitment. We found that ExComs with 50\%, 60\%, $70 \%, 80 \%$, and $90 \%$ response rates were statistically indistinguishable from ExComs with $100 \%$ response rate on these dimensions. We thus included data from any ExCom with at least a 50\% response rate from its ExCom members. Further, to ensure that we do not draw conclusions about the ExCom from too few surveys, we included in our analysis only ExComs with three or more respondents. We thus had sufficiently complete data on 182 (53\%) ExComs to include them in our analysis of questions relying on aggregated data from our ExCom Leader Survey.

Measures of public recognition and the civic and political context.One of the major concerns in our study and in the literature on organizational effectiveness is the validity of our measure of public recognition. This is especially true for studies like ours that rely primarily on reports from a single individual. Prior research provides mixed evidence on the validity of self-report measures with some studies, finding strong congruence between subjective and objective measures (Kalleberg and Moody 1996) or between independent evaluations from different observers or constituencies (Gormley 1982). Other studies present a less favorable assessment. For example, in a study of social service providers, Herman and Renz (1997) used ratings by staff, funders, and board members, finding low correlations across these three groups; however, in a separate analysis of the most and least effective organizations, they found much higher levels of agreement across raters, suggesting that individuals may be better able to distinguish between doing very well, very poorly, or somewhere between (Herman and Renz 1998, 2000).

We looked closely at the data we collected for evidence to help judge the validity of our public recognition measure. Broadly, we asked whether 


\section{American Journal of Sociology}

there was (1) consistency between the chair and the ExCom and (2) to what degree the chair's perception matched other objective indicators. To assess consistency between the chair and the ExCom, we identified four questions on the chair's phone survey that had comparable counterparts on the ExCom Leader Survey. This included measures of whether the group was getting better or worse than in the past, how important political influence is in organizational goal setting, how inclusive decisionmaking processes are, and whether the organization builds on the skills and expertise of its members. In all four domains, we found consistency between the chair's individual response and the ExCom's general assessment (details available upon request).

We can also gauge the chair's trustworthiness by examining her subjective response to questions about the political friendliness of the community with objective community indicators. To develop the self-report measure of civic and political context, we drew on the chair's response to six questions in our phone interview. Analyses showed that the chair's assessment was highly correlated with two other measures of context: the density of Sierra Club membership $(r=.460 ; P<.05)$ and a scale of objective social and political indicators based on the number of civic groups per capita, Republican presidential voters in 2000 as a proportion of all voters (reverse coded), the proportion of college graduates (ages 25 and older), and the proportion college students $(r=.53 ; P<.05)$.

\section{APPENDIX B}

Public Recognition Scale Items

State government leaders consult with us on environmental issues. Local government leaders consult with us on environmental issues.

Officials at public agencies consult with us on environmental issues.

The local media turns to us as an important spokesperson on environmental issues.

Our group's [chapter's] activities and positions are covered regularly in the local media.

Candidates for local office place a high value on our endorsement. 
Civic Associations That Work

\section{APPENDIX C}

Leader Development Scale Items

Managing self:

Listening to other people

Accepting responsibility

Thinking creatively

Accepting criticism

Managing my time

Managing others:

Providing others with support to do their work well

Asking for help

Asking people to volunteer

Delegating responsibility

Coaching and mentoring others

Challenging others to be more effective

Holding others accountable

Managing tasks:

Organizing and running a meeting

Working effectively with public officials

Working effectively in coalition

Speaking in public

Planning and carrying out a campaign

Working with the media

Managing internal conflict 
American Journal of Sociology

APPENDIX D

Leadership Team Interdependence Scale Items

Shared goal:

Our ExCom has clarity about what we are supposed to do.

All the members of our ExCom have a clear sense of what we are supposed to do.

Our ExCom has explicit group discussions about whether or not to undertake a project.

Collective planning:

Our ExCom works collectively to develop our game plans.

Accountability:

I have people who are accountable to me.

Our ExCom holds people accountable for doing what they say they will do.

Collaboration:

I have to work with other members of a team to do my work.

A lot of communication and coordination is necessary with other members to generate outcomes.

I depend heavily on other members to get the work done.

Shared norms:

Expectations for member behavior on this ExCom are clear.

We agree about how members are expected to behave.

Our ExCom holds members accountable for meeting group expectations. 


\section{Civic Associations That Work}

\section{APPENDIX E}

Program and Support Activities: Scale Items

Conservation program:
Members contact officials
Members write letters to editor
Contacting local media
Attending public hearings
Issuing press releases
Sponsoring petitions/tabling
Participate in community events
Holding press conferences
Sponsoring rallies/marches
Presenting in public schools
Relating with other organizations
Relating with community leaders
Relating with public officials
Meeting with government agencies
Meeting with legislators
Presenting at public meetings
Relating with local media
Meeting with advisory committees
Relating with business leaders
Participating in lawsuits
Drafting policy/legislation

Conservation program:

Members write letters to editor

Contacting local media

Attending public hearings

Issuing press releases

Sponsoring petitions/tabling

Participate in community events

Holding press conferences

Sponsoring rallies/marches

Presenting in public schools

Relating with community leaders

Relating with public officials

Meeting with legislators

Presenting at public meetings

Relating with local media

Meeting with advisory committees

Participating in lawsuit
Elections program:

Endorsing candidates/issues

Mobilizing voters

Promoting candidates to the public

Recruiting volunteers for candidates

Sponsoring a debate/forum

Sponsoring canvassing

Outings program:

Hiking/biking trips

Sponsor cleanup/restoration

Service outings

Backpacking/mountain climbing

Technical trips

Support activities:

Training programs

Organize retreats

Social events

Celebrations

Send materials to new members

Make personal contact to new members

Hold meeting for new members 


\section{APPENDIX F}

TABLE F1

Correlation Matrix for Organizational Variables

\begin{tabular}{|c|c|c|c|c|c|c|c|c|c|c|c|c|c|}
\hline & 1 & 2 & 3 & 4 & 5 & 6 & 7 & 8 & 9 & 10 & 11 & 12 & 13 \\
\hline 1 & 1.00 & & & & & & & & & & & & \\
\hline 2 & $.27 *$ & $\ldots$ & & & & & & & & & & & \\
\hline 3 & -.12 & -.03 & . . . & & & & & & & & & & \\
\hline 4 & .14 & $.25^{*}$ & $.25^{*}$ & $\ldots$ & & & & & & & & & \\
\hline 5 & $.37 *$ & .09 & .01 & $.43^{*}$ & . . & & & & & & & & \\
\hline 6 & $.32 *$ & $.46^{*}$ & .12 & $.34 *$ & .10 & $\ldots$ & & & & & & & \\
\hline 7 & .13 & $.22 *$ & .00 & -.02 & -.04 & .17 & . . & & & & & & \\
\hline 8 & .20 & $.35^{*}$ & .07 & $.28 *$ & .16 & $.35^{*}$ & .17 & . . . & & & & & \\
\hline 9 & $.33^{*}$ & $.32 *$ & -.02 & .02 & -.06 & $.51^{*}$ & $.21^{*}$ & $.28 *$ & $\ldots$ & & & & \\
\hline 10 & $.44^{*}$ & $.27 *$ & -.08 & .13 & .17 & $.32 *$ & .11 & .09 & $.20 *$ & . . & & & \\
\hline 11 & $.55^{*}$ & $.31^{*}$ & .03 & .07 & .04 & $.38^{*}$ & .20 & $.24^{*}$ & $.34 *$ & $.46^{*}$ & . . . & & \\
\hline 12 & $.45^{*}$ & $.28^{*}$ & .01 & $.45 *$ & $.27 *$ & $.28 *$ & .05 & $.27 *$ & $.27 *$ & $.30 *$ & $.47 *$ & . . . & \\
\hline 13 & $.23 *$ & $.41^{*}$ & -.15 & .10 & .10 & $.32 *$ & .16 & $.44^{*}$ & $.45^{*}$ & .18 & $.21^{*}$ & .17 & 1.00 \\
\hline
\end{tabular}

Note. $-1=$ public recognition, $2=$ member engagement, $3=$ transfer revenue, $4=$ members, $5=$ civic and political context, $6=$ core activists, $7=$ leadership interdependence, $8=$ local funds raised, $9=$ support activity, $10=$ organizational networks, $11=$ conservation activity, $12=$ election activity, 13 = outings activity.

$* P<.05$ 


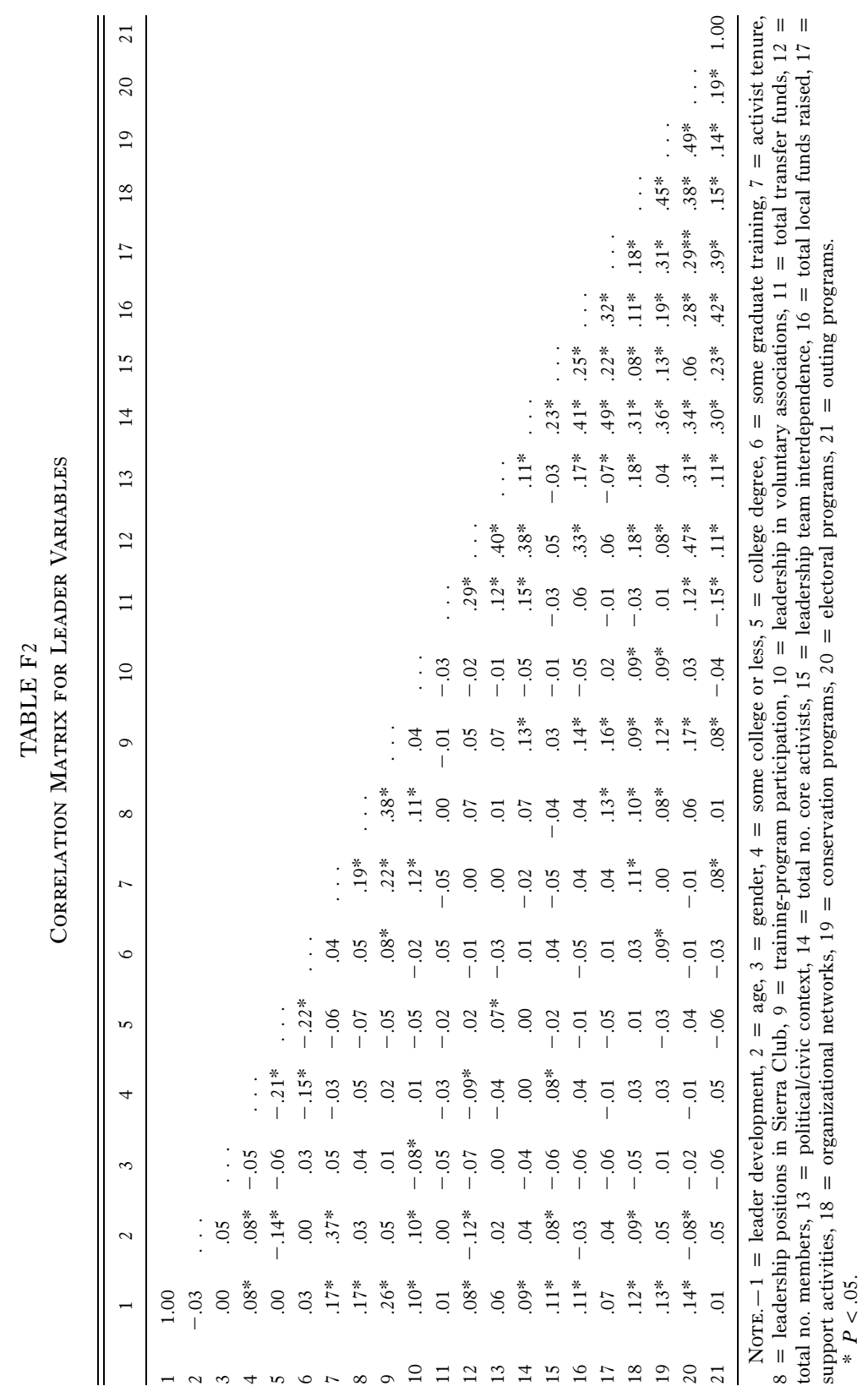

1235 


\section{American Journal of Sociology}

\section{REFERENCES}

Aldrich, Howard E. 1999. Organizations Evolving. London: Sage.

Amenta, Edwin, Neal Caren, and Sheera Joy Olasky. 2005a. "Age for Leisure? Political Mediation and the Impact of the Pension Movement on U.S. Old-Age Policy." American Sociological Review 70:516-38.

2005b. "Newspaper Coverage of Social Movement Organizations in the 20th Century." Contexts 4:48-49.

Amenta, Edwin, and Michael P. Young. 1999. "Making an Impact: Conceptual and Methodological Implications of the Collective Goods Criterion.” In How Social Movements Matter, edited by Marco Giugni, Doug McAdam, and Charles Tilly. Minneapolis: University of Minnesota Press.

Aminzade, Ron, Jack A. Goldstone, and Elizabeth Perry. 2001. "Leadership Dynamics and the Dynamics of Contention." Pp. 126-53 in Silence and Voice in the Study of Contentious Politics, edited by Ron R. Aminzade, Jack A. Goldstone, Doug McAdam, Elizabeth J. Perry, W. H. Sewell, Jr., Sidney Tarrow, and Charles Tilly. Cambridge: Cambridge University Press.

Andrews, Kenneth T. 1997. "The Impacts of Social Movements on the Political Process: The Civil Rights Movement and Black Electoral Politics in Mississippi." American Sociological Review 62:800-819.

. 2001. "Social Movements and Policy Implementation: The Mississippi Civil Rights Movement and the War on Poverty, 1965-1971." American Sociological Review 66:71-95.

2004. Freedom Is a Constant Struggle: The Mississippi Civil Rights Movement and Its Legacy. Chicago: University of Chicago Press.

Andrews, Kenneth T., and Bob Edwards. 2004. "Advocacy Organizations in the U.S. Political Process." Annual Review of Sociology 30:479-506.

—. 2005. "The Organizational Structure of Local Environmentalism." Mobilization 10:213-34

Armstrong, Elizabeth A. 2005. "From Struggle to Settlement: The Crystallization of a Field of Lesbian/Gay Organizations in San Francisco, 1969-1973." Pp. 161-87 in Social Movements and Organization Theory, edited by Gerald F. Davis, Doug McAdam, W. Richard Scott, and Mayer N. Zald. Cambridge: Cambridge University Press.

Barakso, Maryann. 2004. Governing Now: Grassroots Activism in the National Organization for Women. Ithaca, N.Y.: Cornell University Press.

Barker, Colin, Alan Johnson, and Michael Lavalette. 2001. "Leadership Matters: An Introduction." In Leadership and Social Movements, edited by Colin Barker, Alan Johnson, and Michael Lavalette. Manchester: Manchester University Press.

Baron, Reuben M., and David A. Kenny. 1986. "The Moderator-Mediator Variable Distinction in Social Psychological Research: Conceptual, Strategic, and Statistical Considerations." Journal of Personality and Social Psychology 51:1173-82.

Baumgartner, Frank R., and Beth L. Leech. 1998. The Importance of Groups in Politics and in Political Science. Princeton, N.J.: Princeton University Press.

Berry, Jeffrey M. 1999. The New Liberalism: The Rising Power of Citizen Groups. Washington, D.C.: Brookings Institution.

Black, J. Stewart, and Hal B. Gregersen. 1997. "Participative Decision-Making: An Integration of Multiple Dimensions." Human Relations 50:859-78.

Bosso, Christopher J. 2005. Environment, Inc.: From Grassroots to Beltway. Lawrence: University Press of Kansas.

Brulle, Robert J. 2000. Agency, Democracy, and Nature: The U.S. Environmental Movement from a Critical Theory Perspective. Cambridge, Mass.: MIT Press.

Burns, James M. 1978. Leadership. New York: Harper \& Row.

Burstein, Paul, Rachel Einwohner, and Jocellyn Hollander. 1995. "The Success of Social 
Civic Associations That Work

Movements: A Bargaining Perspective.” Pp. 275-95 in The Politics of Social Protest, edited by J. Craig Jenkins and Bert Klandermans. Minneapolis: University of Minnesota Press.

Cameron, Kim S. 1986. "Effectiveness as Paradox: Consensus and Conflict in Conceptions of Organizational-Effectiveness." Management Science 32:539-53.

Campbell, John L. 2005. "Where Do We Stand? Common Mechanisms in Organization and Social Movement Research." Pp. 41-68 in Social Movements and Organization Theory, edited by Gerald F. Davis, Doug McAdam, W. Richard Scott, and Mayer N. Zald. Cambridge: Cambridge University Press.

Clemens, Elisabeth S., and Debra C. Minkoff. 2004. "Beyond the Iron Law: Rethinking the Place of Organizations in Social Movement Research." Pp. 155-70 in The Blackwell Companion to Social Movements, edited by David A. Snow, Sarah A. Soule, and Hanspeter Kriesi. Malden, Mass.: Blackwell.

Cohen, Michael P. 1988. The History of the Sierra Club: 1892-1970. San Francisco: Sierra Club Books.

Cress, Daniel M., and David A. Snow. 1996. "Mobilization at the Margins: Resources, Benefactors, and the Viability of Homeless Social Movement Organization." American Sociological Review 61:1089-1109.

— 2000. "The Outcomes of Homeless Mobilization: The Influence of Organization, Disruption, Political Mediation, and Framing." American Journal of Sociology 105:1063-1104.

Davis, Gerald F., Doug McAdam, W. Richard Scott, and Mayer N. Zald, eds. 2005. Social Movements and Organization Theory. New York: Cambridge University Press.

Day, David V. 2001. "Leadership Development: A Review in Context.” Leadership Quarterly 11:581-613.

Devall, William. 1970. "The Governing of a Voluntary Organization: Oligarchy and Democracy in the Sierra Club." Eugene: University of Oregon Press.

Diani, Mario, and Doug McAdam, eds. 2003. Social Movements and Networks: Relational Approaches to Collective Action. Oxford: Oxford University Press.

Dunlap, Riley E., and Angela G. Mertig. 1992. "The Evolution of the U.S. Environmental Movement from 1970 to 1990: An Overview." Pp. 1-10 in American Environmentalism: The U.S. Environmental Movement, 1970-1990, edited by Riley E. Dunlap and Angela G. Mertig. New York: Taylor \& Francis.

Edwards, Bob, and Sam Marullo. 1995. "Organizational Mortality in a Declining Social Movement: The Demise of Peace Movement Organizations in the End of the Cold War Era." American Sociological Review 60:908-27.

Edwards, Bob, and John D. McCarthy. 2004. "Strategy Matters: The Contingent Value of Social Capital in the Survival of Local Social Movement Organizations." Social Forces 83:621-51.

Eisinger, Peter. 1973. "The Conditions of Protest Behavior in American Cities." American Political Science Review 67:11-28.

Fiorito, Jack, Paul Jarley, and John Thomas Delaney. 1995. "National Union Effectiveness in Organizing: Measures and Influences." Industrial and Labor Relations Review 48:613-35.

Galaskiewicz, Joseph. 1985. "Interorganizational Relations." Annual Review of Sociology 11:281-304.

Gamson, William. 1990. The Strategy of Social Protest. Belmont: Wadswoth.

Gamson, William A., and David S. Meyer. 1996. "Framing Political Opportunity." In Comparative Perspectives on Social Movements: Political Opportunities, Mobilizing Structures, and Cultural Framings, edited by Doug McAdam, John D. McCarthy, and Mayer N. Zald. Cambridge: Cambridge University Press.

Ganz, Marshall. 2000. "Resources and Resourcefulness: Strategic Capacity in the 


\section{American Journal of Sociology}

Unionization of California Agriculture, 1959-1966.” American Journal of Sociology 105:1003-62.

. 2004. "Why David Sometimes Wins: Strategic Capacity in Social Movements." In Rethinking Social Movements: Structure, Meaning and Emotion, edited by James Jasper and Jeff Goodwin. Lanham, Md.: Rowman \& Littlefield.

. 2009. "Leading Change: Leadership, Organization and Social Movements." In Handbook of Leadership Theory and Practice, edited by Nitin Noria and Rakesh Kuhrana. Cambridge, Mass.: Harvard Business School Press.

Ganz, Marshall, Kim Voss, Teresa Sharpe, Carl Somers, and George Strauss. 2004. "Against the Tide: Projects and Pathways of the New Generation of Union Leaders, 1984-2001." In Rebuilding Labor: Organizing and Organizers in the New Union Movement, edited by Ruth Milkman and Kim Voss. Ithaca, N.Y.: Cornell University Press.

Gecan, Mike. 2004. "Three Public Cultures." Pp. 151-66 in Going Public: An Organizer's Guide to Citizen Action. New York: Anchor.

Giugni, Marco G. 1998. "Was It Worth the Effort? The Outcomes and Consequences of Social Movements." Annual Review of Sociology 24:371-93.

Goldstone, Jack. 1980. "The Weakness of Organization: A New Look at Gramson's The Strategy of Social Protest." American Journal of Sociology 85:1017-42.

Goodwin, Jeff, and James M. Jasper. 1999. "Caught in a Winding, Snarling Vine: The Structural Bias of Political Process Theory.” Sociological Forum 14:27-54.

Gormley, William T., Jr. 1982. "Alternative Models of the Regulatory Process: Public Utility Regulation in the States." Western Political Quarterly 35:297-313.

Gottlieb, Robert. 1993. Forcing the Spring: The Transformation of the American Environmental Movement. Washington, D.C.: Island Press.

Greve, Henrich R., Jo-Ellen Pozner, and Hayagreeva Rao. 2006. "Vox Populi: Resource Partitioning, Organizational Proliferation, and the Cultural Impact of the Insurgent Microradio Movement." American Journal of Sociology 112:802-37.

Hackman, J. Richard. 2002. Leading Teams: Setting the Stage for Great Performances. Cambridge, Mass.: Harvard Business School Press.

Hammer, Tove E., and David L. Wazeter. 1993. "Dimensions of Local Union Effectiveness." Industrial and Labor Relations Review 46:302-19.

Haveman, Heather A., Hayagreeva Rao, and Srikanth Paruchuri. 2007. "The Winds of Change: The Progressive Movement and the Bureaucratization of Thrift." American Sociological Review 72:117-42.

Herman, Robert D., and David O. Renz. 1997. "Multiple Constituencies and the Social Construction of Nonprofit Organization Effectiveness." Nonprofit and Voluntary Sector Quarterly 26:185-206.

1998. "Nonprofit Organizational Effectiveness: Contrasts between Especially Effective and Less Effective Organizations." Nonprofit Management and Leadership 9:23-38.

. 2000. "Board Practices of Especially Effective and Less Effective Local Nonprofit Organizations." American Review of Public Administration 30:146-60.

- 2004. "Doing Things Right: Effectiveness in Local Nonprofit Organizations, a Panel Study." Public Administration Review 64:694-704.

Inglehart, Ronald. 1990. "Values, Ideology, and Cognitive Mobilization in New Social Movements." Pp. 23-42 in Challenging the Political Order, edited by Russell J. Dalton and Manfred Kuechler. New York: Oxford University Press.

Jasper, James M. 2004. "A Strategic Approach to Collective Action: Looking for Agency in Social Movement Choices." Mobilization 9:1-16.

Jenkins, J. Craig, David Jacobs, and Jon Agnone. 2003. "Political Opportunities and African-American Protest, 1948-1997." American Journal of Sociology 109:277-303.

Jenkins, J. Craig, and Charles Perrow. 1977. "Insurgency of the Powerless: Farm Worker Movements (1946-1972)." American Sociological Review 42:249-68. 


\section{Civic Associations That Work}

Jordan, Grant, and William A. Maloney. 1998. "Manipulating Membership: SupplySide Influences on Group Size.” British Journal of Political Science 28:389-409.

Kalleberg, Arne L., and James Moody. 1996. "Human Resource Management and Organizational Peformance." Pp. 113-29 in Organizations in America, edited by Arne L. Kalleberg, David Knoke, Peter V. Marsden, and Joe L. Spaeth. London: Sage.

Kanter, Rosabeth M. 1977. Men and Women of the Corporation. New York: Basic Books.

Kanter, Rosabeth Moss, and Derick Brinkerhoff. 1981. "Organizational Performance: Recent Developments in Measurement." Annual Review of Sociology 7:321-49.

King, B. G., and S. A. Soule. 2007. "Social Movements as Extra-institutional Entrepreneurs: The Effect of Protests on Stock Price Returns.” Administrative Science Quarterly 52:413-42.

Kitschelt, Herbert P. 1986. "Political Opportunity Structures and Political Protest: Antinuclear Movements in Four Democracies." British Journal of Political Science 16: $57-85$.

Knoke, David. 1990a. Organizing for Collective Action: The Political Economies of Associations. New York: Aldine de Gruyter.

- 1990b. Political Networks: The Structural Perspective. Cambridge: Cambridge University Press.

Knoke, David, and David Prensky. 1984. "What Relevance Do Organization Theories Have for Voluntary Associations?” Social Science Quarterly 65:3-20.

Kurzman, Charles. 1996. "Structural Opportunity and Perceived Opportunity in SocialMovement Theory: The Iranian Revolution of 1979.” American Sociological Review 61:153-70.

Leighley, Jan. 1996. "Group Membership and the Mobilization of Political Participation." Journal of Politics 58:447-63.

Lieberson, Stanley, and James F. O'Connor. 1972. "Leadership and Organizational Performance: A Study of Large Corporations." American Sociological Review 37: $117-30$.

Lipset, Seymour Martin, Martin Trow, and James. S. Coleman. 1956. Union Democracy: The Internal Politics of the International Typographical Union. New York: Free Press.

Long, J. Scott, and Jeremy Freese. 2006. Regression Models for Categorical Dependent Variables Using Stata. College Station, Tex.: Stata Press.

Martin, Andrew W. 2008. "The Institutional Logic of Union Organizing and the Effectiveness of Social Movement Repertoires.” American Journal of Sociology 113: $1067-1103$.

McAdam, Doug, and W. Richard Scott. 2005. "Organizations and Movements." Pp. 4-40 in Social Movements and Organization Theory, edited by Gerald F. Davis, Doug McAdam, W. Richard Scott, and Mayer N. Zald. Cambridge: Cambridge University Press.

McAdam, Doug, Sidney Tarrow, and Charles Tilly. 2001. Dynamics of Contention. Cambridge: Cambridge University Press.

McCammon, Holly J., Kelly E. Campbell, Ellen M. Granberg, and Christine Mowery. 2001. "How Movements Win: Gendered Opportunity Structures and US Women's Suffrage Movements, 1866 to 1919." American Sociological Review 66:49-70.

McCammon, Holly J., Soma Chaudhuri, Lyndi Hewitt, Courtney Sanders Muse, Harmony D. Newman, Carrie Lee Smith, and Teresa M. Terrell. 2008. "Becoming Full Citizens: The U.S. Women's Jury Rights Campaigns, the Pace of Reform, and Strategic Adaptation." American Journal of Sociology 113:1104-47.

McCarthy, John D. 2005. "Persistence and Change among Nationally Federated Social Movements." Pp. 193-225 in Social Movements and Organization Theory, edited by 


\section{American Journal of Sociology}

Gerald F. Davis, Doug McAdam, W. Richard Scott, and Mayer N. Zald. Cambridge: Cambridge University Press.

McCarthy, John D., and Mark Wolfson. 1996. "Resource Mobilization by Local Social Movement Organizations: Agency, Strategy, and Organization in the Movement against Drinking and Driving." American Sociological Review 61:1070-88.

McCarthy, John D., Mark Wolfson, David P. Barker, and Elaine Mosakowski. 1988. "The Founding of Social Movement Organizations: Local Citizens' Groups Opposing Drunken Driving." Pp. 71-84 in Ecological Models of Organizations, edited by Glenn R. Carroll. Cambridge, Mass.: Ballinger.

McCarthy, John D., and Mayer N. Zald. 2002. "The Enduring Vitality of the Resource Mobilization Theory of Social Movements." Pp. 533-65 in Handbook of Sociological Theory, edited by Jonathan H. Turner. New York: Kluwer Academic/Plenum.

Mesch, Debra, Marvin Lew, David W. Johnson, and Roger T. Johnson. 1988. "Impact of Positive Interdependence and Academic Group Contingencies on Achievement." Journal of Social Psychology 128:345-52.

Meyer, David S. 2004. "Protest and Political Opportunities." Annual Review of Sociology 30:125-45.

Meyer, David S., and Sidney Tarrow, eds. 1998. The Social Movement Society: Contentious Politics for a New Century. Lanham, Md.: Rowman \& Littlefield.

Michels, Robert. 1959. Political Parties. New York: Dover.

Miller, L., and Robert L. Hamblin. 1963. "Interdependence, Differential Rewarding, and Productivity." American Sociological Review 28:768-78.

Minkoff, Debra C. 1993. "The Organization of Survival: Women's and Racial-Ethnic Voluntarist and Activist Organizations, 1955-1985." Social Forces 71:887-908.

Minkoff, Debra C., and John D. McCarthy. 2005. "Reinvigorating the Study of Organizational Processes in Social Movements." Mobilization 10:289-308.

Mitchell, Terence R., and William S. Silver. 1990. "Individual and Group Goals When Workers are Interdependent: Effects on Task Strategies and Performance.” Journal of Applied Psychology 75:185-93.

Morrill, Calvin, Mayer N. Zald, and Hayagreeva Rao. 2003. "Convert Political Conflict in Organizations: Challenges from Below." Annual Review of Sociology 29:391-415.

Morris, Adon D., and Suzanne Staggenborg. 2004. "Leadership in Social Movements." in The Blackwell Companion to Social Movements, edited by David A. Snow, Sarah A. Soule, and Hanspeter Kriesi. Malden, Mass.: Blackwell.

Mundo, Philip. 1992. "The Sierra Club.” Pp. 167-201 in Interest Groups, edited by Philip Mundo. Chicago: Nelson-Hall.

Nonprofit Sector Strategy Group. 2000. "The Nonprofit Contribution to Civic Participation and Advocacy." Draft statement for public discussion, Aspen Institute, Washington, D.C.

Oster, Sharon M. 1996. "Nonprofit Organizations and Their Local Affiliates: A Study in Organizational Forms." Journal of Economic Behavior and Organization 30: 83-95.

Pennings, J. M. 1976. "Dimensions of Organizational Influence and Their Effectiveness Correlates." Administrative Science Quarterly 21:688-99.

Polletta, Francesca. 2002. Freedom Is an Endless Meeting: Democracy in American Social Movements. Chicago: University of Chicago Press.

Preacher, Kristopher J., and Andrew F. Hayes. 2004. "SPSS and SAS Procedures for Estimating Indirect Effects in Simple Mediation Models." Behavior Research Methods, Instruments, and Computers 36:717-31.

Putnam, Robert. 2000. Bowling Alone: The Collapse and Revival of American Community. New York: Simon \& Schuster.

Reger, Jo, and Suzanne Staggenborg. 2006. "Patterns of Mobilization in Local Movement Organizations: Leadership and Strategy in Four National Organization for Women Chapters." Sociological Perspectives 49:297-323. 
Civic Associations That Work

Rothenberg, Lawrence S. 1992. Linking Citizens to Government: Interest Group Politics at Common Cause. Cambridge: Cambridge University Press.

Salancik, Gerald R., and Jeffrey Pfeffer. 1977. "Constraints on Administrator Discretion: The Limited Influence of Mayors on City Budgets." Urban Affairs Review 12: 475-98.

Schlozman, Kay Lehman, and John T. Tierney. 1986. Organized Interests and American Democracy. New York: Harper \& Row.

Schneiberg, Marc, and Sarah A. Soule. 2005. "Institutionalization as a Contested, Multilevel Process." Pp. 122-60 in Social Movements and Organization Theory, edited by Gerald F. Davis, Doug McAdam, W. Richard Scott, and Mayer N. Zald. Cambridge: Cambridge University Press.

Scott, W. Richard. 2002. Organizations: Rational, Natural, and Open Systems. Englewood Cliffs, N.J.: Prentice-Hall.

Selznick, Phillip. 1949. TVA and the Grass Roots: A Study in the Sociology of Formal Organization. Berkeley: University of California Press.

Shaiko, Ronald G. 1999. Voices and Echoes for the Environment: Public Interest Representation in the 1990s and Beyond. New York: Columbia University Press.

Skocpol, Theda. 2003. Diminished Democracy: From Membership to Management. Norman: University of Oklahoma.

Skocpol, Theda, Marshall Ganz, and Ziad Munson. 2000. "A Nation of Organizers: The Institutional Origins of Civic Voluntarism in the United States." American Political Science Review 94:527-46.

Smith, David Horton. 2000. Grassroots Associations. Thousand Oaks, Calif.: Sage.

Smith, Richard A. 1995. "Interest Group Influence in the U.S. Congress." Legislative Studies Quarterly 20:89-139.

Snow, Donald. 1992. Inside the Environmental Movement: Meeting the Leadership Challenge. San Francisco: Island Press.

Soule, Sarah A., and Brayden G. King. 2006. "The Stages of the Policy Process and the Equal Rights Amendment, 1972-1982." American Journal of Sociology 111: 1871-1909.

Staggenborg, Suzanne. 1991. The Pro-choice Movement: Organization and Activism in the Abortion Conflict. New York: Oxford University Press.

Stolle, Dietlind. 1998. "Bowling Together, Bowling Alone: The Development of Generalized Trust in Voluntary Associations." Political Psychology 19:497-525.

Swaminathan, Anand, and James B. Wade. 2001. "Social Movement Theory and the Evolution of New Organizational Forms." Pp. 286-313 in The Entrepreneurship Dynamic: Origins of Entrepreneurship and the Evolution of Industries, edited by Claudia Bird Schoonhoven and Elaine Romanelli. Stanford, Calif.: Stanford University Press.

Tarrow, Sidney. 1998. Power in Movement: Social Movements, Collective Action and Mass Politics in the Modern State. Cambridge: Cambridge University Press.

Thomas, Edwin J. 1957. "Effects of Facilitative Role Interdependence on Group Functioning." Human Relations 10:347-66.

Tocqueville, Alexis de. (1835-40) 1969. Democracy in America. Garden City, N.Y.: Doubleday, Anchor Books.

Uzzi, Brian. 1996. "The Sources and Consequences of Embeddedness for the Economic Performance of Organizations: The Network Effect.” American Sociological Review 61:674-98.

Vogus, Timothy J., and Gerald F. Davis. 2005. "Elite Mobilizations for Antitakeover Legislation, 1982-1990." Pp. 96-121 in Social Movements and Organization Theory, edited by Gerald F. Davis, Doug McAdam, W. Richard Scott, and Mayer N. Zald. Cambridge: Cambridge University Press.

Wageman, Ruth. 1995. "Interdependence and Group Effectiveness." Administrative Science Quarterly 40:145-80. 


\section{American Journal of Sociology}

. 2000. "The Meaning of Interdependence." In Groups at Work: Advances in Theory and Research, edited by M. E. Turner. Hillsdale, N.J.: Erlbaum.

Walker, Edward T. 2009. "Privatizing Participation: Civic Change and the Organizational Dynamics of Grassroots Lobbying Firms." American Sociological Review $74: 83-105$.

Walker, Jack L. 1991. Mobilizing Interest Groups in America: Patrons, Professions and Social Movements. Ann Arbor: University of Michigan Press.

Walton, Richard. 1985. "From Control to Commitment in the Workplace." Harvard Business Review 63:76-84.

Webb, Ronald J. 1974. "Organizational Effectiveness and the Voluntary Organization." Academy of Management Journal 17:663-77.

Weir, Margaret, and Marshall Ganz. 1997. "Reconnecting People and Politics." Pp. 149-71 in The New Majority: Toward a Popular Progressive Politics, edited by Stanley B. Greenberg and Theda Skocpol. New Haven, Conn.: Yale University Press. Wilson, James Q. 1973. Political Organizations. New York: Basic Books.

Yuchtman, Ephraim, and Stanley E. Seashore. 1967. "A System Resource Approach to Organizational Effectiveness." American Sociological Review 32:891-903.

Zald, Mayer N. 1970. Organizational Change: The Political Economy of the YMCA. Chicago: University of Chicago Press. 